\title{
ALGUNAS CUESTIONES RELEVANTES SOBRE EL DERECHO AL HONOR Y LA RESPONSABILIDAD CIVIL EN PARTICULAR, SOBRE EL DAÑO MORAL, EL ARTÍCULO 2331 DEL CÓDIGO CIVIL, Y LA LEGITIMACIÓN ACTIVA*
}

Cristián Andrés Larrain Páez**

\section{RESUMEN}

El artículo tiene como objetivo identificar los principales problemas prácticos que se presentan en relación con el honor y la responsabilidad civil y, al mismo tiempo, exponer, cómo los tribunales nacionales resuelven actualmente dichos problemas. Dentro de éstos, la exposición se centra en la aplicación del artículo 2331 del Código Civil, en la procedencia de la titularidad del derecho al honor a personas jurídicas, y en la procedencia y montos de indemnizaciones de daños morales por vulneración del derecho al honor.

Palabras claves: responsabilidad, honor, persona jurídica, daño moral.

\section{ABSTRACT}

The article aims to identify the main practical problems that arise in the relationship of honor and liability, and at the same time, to show how national courts currently solve these problems. Among these, the exposition focuses on the application of article 2331 of the Chilean Civil Code, on the legitimacy of recogizing the right of reputation to companies and

* Este trabajo corresponde a una versión extendida de la ponencia presentada en las Jornadas Nacionales de Derecho Civil del año 2010, publicada en el libro que contiene las actas correspondientes, Estudios de Derecho Civil VI. La presente investigación ha sido financiada por la Universidad del Desarrollo, con cargo al proyecto de investigación interno número 23.400.027 (2010).

** Doctor en Derecho Privado por la Universidad Carlos III de Madrid, master en Derecho Privado por la Universidad Carlos III de Madrid, profesor de Derecho Civil de la Universidad del Desarrollo, sede Concepción. Dirección postal: Ainavillo 45, Concepción, Chile. Artículo recibido el 16 de junio de 2011 y aceptado para su publicación el 23 de noviembre de 2011. Correo electrónico: cristian_larrain@yahoo.com. 
corporations, and on the admissibility and amount of compensation for non-pecuniary loss for defamation and injury to reputation.

Key words: liability, reputation, damages, corporation, non-pecuniary loss.

\section{Resumo}

$\mathrm{O}$ artigo tem como objetivo identificar os principais problemas práticos que se apresentam em relação à honra e à responsabilidade civil e, ao mesmo tempo, expor como os Tribunais nacionais resolvem atualmente ditos problemas. Dentro disso, a exposição centra-se na aplicação do artigo 2331 do Código Civil Chileno, na procedência da titularidade do direito à honra às pessoas jurídicas, e na procedência e somas de indenização de danos morais por vulneração do direito à honra.

Palavras chaves: responsabilidade, honra, pessoa jurídica, dano moral.

El presente trabajo tiene como objetivo principal, exponer la relación existente en la práctica entre el derecho a la honra garantizado en la Constitución, y la responsabilidad civil, y los principales problemas que se han presentado en la práctica respecto a esta cuestión. En pocas líneas, se persigue delimitar en qué situaciones y en qué medida se justifica identificar la lesión a un derecho fundamental abstracto y difuso como lo es el honor, con la ocurrencia de daños, tanto patrimoniales como extrapatrimoniales. Y en forma paralela, evaluar la procedencia de indemnizaciones por daños morales por lesiones al honor, en un contexto -en apariencia- exclusivamente patrimonial, donde lo relevante son los volúmenes y oportunidades de negocios, las alzas o bajas en las ventas, la cotización en bolsa y otros índices y valores que usualmente son relevantes en el ámbito empresarial.

En este contexto, luego de exponer el problema en general, se abordará la dicotomía honor-prestigio, en circunstancias de que se los suele considerar como instituciones análogas. Se analizará, también, la relación que existiría entre la ocurrencia de daños morales y las vulneraciones al al honor, para lo cual será necesario abordar dos cuestiones que parecen relevantes respecto a la materia:

- la situación del artículo 2331 del Código Civil en la jurisprudencia, por ser una norma que se refiere directamente al problema. 
- la procedencia del derecho al honor en las personas jurídicas, en consideración a que una parte importante de los operadores del mercado se encuentran configurados como entidades personificadas.

Se abordarán, asimismo, algunas cuestiones calificables de "limítrofes", como el honor de los fallecidos y de las entidades no personificadas. El relato se cerrará con una exposición sobre el "estado actual de la cuestión" en la jurisprudencia reciente de las cortes de apelaciones y de la Corte Suprema, la que permitirá contrastar las propuestas teóricas, con la forma en que los tribunales resuelven los problemas en la práctica.

\section{EL TRASFONDO DEL PROBLEMA}

En la actualidad, es posible observar un importante número de resoluciones judiciales, tanto de los tribunales superiores como inferiores del país, que resuelven casos en los que se ha afectado el prestigio de personas físicas y jurídicas -por lo general configuradas como empresas-. Particularmente, en supuestos de inclusión errónea de empresas o de sus titulares en boletines comerciales y públicos de deudores morosos o de difamación por atribuírseles conductas reprochables ${ }^{1}$. En estos casos, la persona o entidad afectada suele reclamar una suma de dinero como compensación pecuniaria ante los hechos lesivos de su reputación, cantidad que por regla general se solicita a título tanto de lucro cesante como de daño moral.

No es poco habitual que en estas situaciones los juzgadores tiendan a prescindir de una prueba objetiva del daño, al acoger las demandas de indemnización de perjuicios. Usualmente, se pone más énfasis en acreditar los hechos que configurarían la lesión al derecho fundamental a la honra, que en las consecuencias perjudiciales que dicha lesión puede haber ocasionado.

En la práctica, además, es común que en estas situaciones se rechazan las peticiones por lucro cesante, por no haberse acreditado en el litigio y

\footnotetext{
${ }^{1}$ Aunque aún es poco usual en nuestra jurisprudencia civil, es posible encontrarse con supuestos en que se demandan indemnizaciones de perjuicios por daños morales causados por intromisiones ilegítimas en el honor del demandante, configuradas por su vinculación con conductas reñidas con la moral o "poco decorosas". Es el caso, por ejemplo, de la SCS de 20 de octubre de 2010, rol 4.612-2010, $3^{\text {a }}$ Sala, en la cual se rechazó el recurso de casación interpuesto por la empresa periodística demandada, quedando firme el fallo que condenaba a indemnizar los perjuicios (fijados en ocho millones de pesos) sufridos por la demandante, quien fue asociada erróneamente a un video en que se mostraba contenido pornográfico. Para la misma hipótesis, pero como demandantes los padres de la mujer asociada a las imágenes, véase la SCA de Santiago de 8 de marzo de 2010, rol 2.884-2009, en la cual se confirmó una indemnización de dos millones de pesos para cada progenitor.
} 
-por el contrario- que se concedan las pretensiones por daño moral, con escasas o nulas referencias a la prueba en los autos. El problema se acentúa aún más, si se considera que, por regla general, esa prueba está dirigida principalmente a acreditar la ocurrencia del hecho ilícito, más que a acreditar la existencia del daño, y que, como se verá más adelante, no es sencillo encontrar parámetros que faciliten el cálculo del monto de la indemnización. En los pleitos, se suele acreditar sólo la inclusión en un boletín público de morosos, y que dicha publicación fue improcedente. Las consecuencias de esos hechos usualmente son difíciles de delimitar, y su prueba resulta mucho menos relevante que lo que es la prueba de los daños en supuestos tradicionales de responsabilidad civil -léase daños físicos o materiales-, donde, al menos, hay consecuencias lesivas evidentes (fallecimiento, pérdida de extremidades, enfermedad, etc.). En el mejor escenario, se presenta prueba de testigos que relatan las consecuencias sicológicas que los hechos habrían causado a los demandantes, pero es extraño el caso en que se ofrezca un peritaje sicológico o similar, para acreditar alteraciones anímicas u otras afecciones que permitan configurar daños extrapatrimoniales.

Todo esto, considerando que, si bien hay hechos que permiten presumir la ocurrencia de daño moral entendido como sinónimo de sufrimientos y pesares, como es el dolor que ocasiona el fallecimiento de un ser querido, 146 en estos supuestos es dudoso que se justifique una presunción judicial de esa envergadura, que deja al demandado casi entregado a una avaluación benévola de los perjuicios, por parte del tribunal.

\section{EL PRESTIGIO Y EL HONOR}

En la teoría, para intentar un análisis coherente de esta cuestión, es necesario abordar distintos problemas. En un primer orden, se debe señalar que en doctrina se suele igualar el prestigio con el honor constitucionalmente garantizado $^{2}$. La relevancia de distinguir entre uno y otro, radica en que el honor, como derecho fundamental y dada su relación directa con la dignidad humana, es inherente a todas las personas sin variación ni distinciones. En cambio, el llamado prestigio, "buen nombre" o "fama", se

\footnotetext{
${ }_{2}^{2}$ Para la situación en España, véase, Manuel Albaladejo, Derecho Civil, 15 a ed., Madrid, Edisofer, 2002, vol. 1, p. 491 y Luis Dízz-Picazo, Antonio Gullón, Sistema de Derecho Civil. Introducción. Derecho de la persona. Autonomía privada. Persona jurídica, $11^{\mathrm{a}}$ ed., Madrid, Tecnos, 2005, p. 344. En Chile, entre otros, Ramón Domínguez Águila, "Aspectos de la constitucionalización del Derecho Civil chileno", en Revista de Derecho y Jurisprudencia, vol. 93, N 3, Santiago, 1996, p. 128, n. 54 (y la misma afirmación se hace por el TC en la sentencia 10 de junio del 2008, rol 943, que se expone más adelante).

${ }^{3} \mathrm{O}$ prestigio profesional o comercial, entre otras expresiones.
} 
construye o adquiere con el tiempo, según la conducta del sujeto. En este orden, se entiende que a diferencia del honor, es un hecho, "una notoriedad adquirida voluntariamente por algunos", en razón de su profesión o de la actividad que desarrollen ${ }^{4}$.

Ahora, sin perjuicio de que parece discutible que el prestigio merezca el mismo tratamiento que el honor como derecho fundamental (pareciera que el primero tiene un rango inferior), el que se acepte la afirmación anterior como válida por gran parte de la doctrina, obliga, al menos, a situarse en ese escenario y analizar el problema desde esa perspectiva, asumiendo que los atentados al prestigio merecerían seguir la misma suerte que las vulneraciones al honor, con lo que la distinción pasaría a ser casi semántica.

\section{EL HONOR Y LOS DAÑOS MORALES}

Luego, asumiendo que el prestigio o reputación comercial de una persona sería asimilable a su derecho a la honra (o al honor, esta distinción terminológica hoy no tiene trascendencia científica $)^{5}$, una de las cuestiones más relevantes en el ámbito teórico es determinar la relación que existiría entre los derechos de la personalidad ( $\mathrm{y}$, en este caso, también fundamentales) y la responsabilidad civil. Un sector respetable de la doctrina comparada considera que el daño moral se identifica con las lesiones a los derechos de la personalidad ${ }^{6}$, lo que en la práctica produce que baste la sola lesión para que se entienda configurado el perjuicio, sin que sea necesario acreditarlo (y así sucede también, en general, en la jurisprudencia europea continental, como la española ${ }^{7}$ la francesa $\left.{ }^{8}\right)$.

${ }^{4}$ Juan José Bonilla SÁnchez, Personas y derechos de la personalidad, Zaragoza, Reus, 2010, p. 103.

${ }^{5}$ Pese a las diferencias conceptuales que se puedan insinuar (aludidas, incluso, en las actas de las sesiones de la Comisión Constituyente), en la actualidad creo que no tiene mucha relevancia distinguir el término 'honra' del 'honor', debiendo considerarse sinónimos (y en Derecho Comparado tiende a optarse, incluso, por el segundo).

${ }^{6}$ Para el contexto europeo general, véase Christian Von BAR, The Common European Law of Torts, Oxford, Oxford Claredon Press, 2000, p. 9. En España, en este sentido -entre otros, José Castán Tobeñas, Derecho civil español, común y foral, $16^{\mathrm{a}}$ ed. revisada y puesta al día por Gabriel García Cantero, Madrid, Reus, 1992, tomo tercero: Derecho de obligaciones. La obligación y el contrato en general, p. 276 y Ricardo de Ángel YáGÜEz, Tratado de Responsabilidad Civil, Madrid, Universidad de Deusto, Civitas, 1993, p. 675. En Chile, entre otros Domínguez Águila (n. 2), p. 132 y n. 66.

${ }^{7}$ Véase al respecto Pedro Grimalt Servera, La protección civil de los derechos al honor, a la intimidad y a la propia imagen, Madrid, Iustel, 2007, p. 161 y ss.

${ }^{8}$ Para el "estado de la cuestión" en la jurisprudencia francesa, véase Suzanne GaLAND Carval, "Non Pecuniary Loss Under French Law", in W.V. Horton Rogers, (dir.), Damages 
Pese a que el planteamiento recién expuesto no está exento de críticas ${ }^{9}$, que se resumen principalmente en que la responsabilidad civil no tendría como función la protección de derechos subjetivos ${ }^{10}$, y en que la lesión a un derecho no necesariamente es equiparable a perjuicio indemnizable ${ }^{11}$, el hecho de que no pocos autores entiendan que la vulneración de un derecho de la personalidad es una de las hipótesis de daños morales ${ }^{12}$, obliga a analizar si esta relación causa-efecto se está aplicando en los casos prácticos. Esto porque si se considera la afirmación anterior como verdadera, y se entiende, a su vez, que el prestigio es identificable con el honor de la persona, las lesiones a él deberían tener como consecuencia la ocasión de daños extrapatrimoniales a la víctima, acreditándose sólo el atentando a la señalada prerrogativa ${ }^{13}$.

En consecuencia, se podría afirmar que en teoría, pese a las objeciones que se pudieran plantear, se ha construido un vínculo entre la responsabilidad civil y la protección del honor (y del prestigio) sumamente cercano, formando parte ambas cuestiones, de una relación causa-efecto prácticamente automática. En la doctrina nacional, parece haber consenso respecto a que las lesiones en el prestigio ajeno (lo que sucedería en casos de inclusiones erróneas en boletines comerciales de deudores morosos)

for Non Pecuniary Loss in a Comparative Perspective, Viena, SpringerWien NewYork, 2001, p. 105 y Philippe Le Tourneau, Droit de la responsabilité et des contrats, $7^{\mathrm{a}}$ ed., Paris, Dalloz, 2008, p. 412 et ss.

9 Véase José Luis Díez Schwerter, El daño extracontractual ante la jurisprudencia. Comentarios, Concepción, Universidad de Concepción, Facultad de Ciencias Jurídicas y Sociales, Fondo de Publicaciones, 1995, p. 71.

${ }^{10}$ Fernando Pantaleón, “Comentarios al artículo 1902”, en Cándido Paz-Ares Rodríguez, Luis Díez-Picazo Ponce de León, Rodrigo Bercovitz, Comentario del Código Civil, Madrid, Ministerio de Justicia, 1993, pp. 1.994-1.995. En contra, argumentando que para que se produzca un daño moral, es necesaria la vulneración de un derecho: Pablo Rodríguez Grez, Responsabilidad extracontractual, Santiago, Editorial Jurídica de Chile, 1999, p. 306 y ss.

${ }^{11}$ Luis Dítz-Picazo, El escándalo del daño moral, Navarra, Thomson Civitas, 2008, p. 80.

${ }^{12}$ En la doctrina chilena, Hernán Corral Talciani, Lecciones de responsabilidad civil extracontractual, Santiago, Editorial Jurídica de Chile, 2004, p. 155 y Ramón Domínguez ÁGUila, "Daño moral contractual. Daño moral de personas jurídicas. Comentario a sentencia de la Corte de Apelaciones de Santiago, de 9 de diciembre de 2003", en Revista de Derecho de la Universidad de Concepción, No 214, Concepción, 2003, p. 184.

${ }^{13}$ En otras palabras, sucede que el daño dejaría de ser el elemento condicionante de la reparación, pasando a serlo la ilicitud o antijuricidad del acto (opción que se tomó a nivel legislativo en España, y que se ha pretendido "importar" a Chile cuando se han presentado proyectos de ley sobre la materia, véase Carlos PeÑa GonZÁlez, "Informe sobre el proyecto de ley de protección del honor y la intimidad de las personas", en Cuadernos de Análisis Jurídicos, Colección de Derecho Privado, Santiago, 2004, vol. I, pp. 86-87. 
pueden generar un daño indemnizable de carácter extrapatrimonial ${ }^{14}$, no obstante, hay quienes discrepan y advierten que la naturaleza del mismo debiera ser, por regla general, patrimonial ${ }^{15}$.

Sin perjuicio de ser una cuestión discutible, pareciera ser que esta última opción es más adecuada, motivo por el cual parece arriesgado afirmar sin prevenciones que una vulneración al honor de una persona será siempre causa de un perjuicio extrapatrimonial, debiendo analizarse otras hipótesis, caso a caso.

\section{EL “OBSTÁCULO” NORMATIVO}

\section{El problema del artículo 2331 del Código Civil}

$\mathrm{Al}$ igual que los códigos de su época, el de Andrés Bello omitió regular e, incluso, referirse a los llamados derechos de la personalidad, particularmente a aquéllos que se suelen denominar "morales", o del "patrimonio moral del individuo": léase honor, intimidad y propia imagen. Esto no implicó que no se destinase al menos una norma para el honor, ubicada en el art. 2331 del $C C^{16}$, que desde un punto de vista formal, restringe las indemnizaciones por daños causados al honor (o al "crédito") ${ }^{17}$ exclusivamente a los daños patrimoniales. Esta regla, que interpretada en forma literal conduce a que no se indemnicen los daños morales causados a las víctimas de vulneraciones de su derecho al honor, ha sido criticada por un amplio

${ }^{14}$ En este sentido, Ramón Domínguez Benavente, Ramón Domínguez Águila, "Indemnización de perjuicios, daño moral, persona jurídica, relación de causalidad. Leyes reguladoras de la prueba. Documentos emanados de terceros. Comentario a Sentencia de la Corte de Apelaciones de Concepción de 2 de noviembre de 1989", en Revista de Derecho de la Universidad de Concepción, $\mathrm{N}^{\circ}$ 190, Concepción, 1991, p. 151 y Carmen Aída Domínguez HidAlgo, "Los derechos de la personalidad y el principio de reparación integral del daño", en Carlos Pizarro Wilson, Estudios de Derecho Civil IV, Santiago, LegalPublishing, 2009, p. 654.

${ }^{15}$ Enrique Barros Bourie, Tratado de responsabilidad civil, Santiago, Editorial Jurídica de Chile, 2006, p. 589.

16 "Las imputaciones injuriosas contra el honor o el crédito de una persona no dan derecho para demandar una indemnización pecuniaria, a menos de probarse daño emergente o lucro cesante, que pueda apreciarse en dinero; pero ni aun entonces tendrá lugar la indemnización pecuniaria, si se probare la verdad de la imputación”. Actualmente es posible ubicar otros artículos referidos al honor e, incluso, relacionados con la responsabilidad civil. El art. 197 del $C C$ contempla la posibilidad de reclamar indemnización de perjuicios, sin distinguir su clase, a quien vea lesionada su "honra" por el ejercicio de una acción de filiación con dicho objeto, o de mala fe. Se pueden señalar, además, los arts. 968 y 1207.

${ }^{17}$ Se podría entender que se refiere a lo que se conoce tradicionalmente como prestigio, con lo que la distinción cobra validez. 
y autorizado sector de la doctrina nacional ${ }^{18}$. Los reclamos se centran en considerarla una disposición arcaica e incompatible con el actual escenario constitucional, el cual tiene como uno de sus pilares básicos el respeto a la dignidad del ser humano.

Más allá de los -válidos- motivos que tienen los autores al abogar por la eliminación (por el medio que sea) de la norma, se debe tener presente que su aplicación estaría circunscrita a vulneraciones al honor que no se configuren como delitos cometidos a través de medios de prensa, dado que se rigen por la ley $\mathrm{N}^{\mathrm{o}} 19.733$, sobre Libertades de Opinión e Información y Ejercicio del Periodismo. Su art. $40^{19}$ admite en forma expresa la procedencia de indemnizaciones por daño moral ante delitos de injuria o calumnia cometidos a través de medios de comunicación. La mezcla de ambas normas no es tan sencilla, sobre todo por el tenor del art. 2331 del $C C$. Una interpretación posible, es entender que si la vulneración al derecho al honor no consistió en un delito criminal, se debería aplicar el art. $2331 \mathrm{del} C C$, aun cuando se haya realizado a través de medios de comunicación, dado que el art. 40 de la ley $\mathrm{N}^{\mathrm{o}}$ 19.733 circunscribiría su aplicación sólo a los delitos de injuria o calumnia ${ }^{20}$. A esto se puede sumar que si se entiende que el art. $2331 \mathrm{del} C C$, al señalar "imputaciones injuriosas", se refiere sólo a aquellas vulneraciones que por su magnitud no son constitutivas de delito criminal, no sería aplicable cuando la lesión al honor consista en un delito criminal, dado que en ese caso la acción se rige por las reglas generales, pero la lectura usual no es ésta ${ }^{21}$.

Como norma excepcional, debería ser interpretada de manera restrictiva, y si se acepta lo anterior, su aplicación quedaría circunscrita a las vulneraciones al honor que por su magnitud y caracteres no son constitutivas de un delito criminal. Es posible ir más lejos aún, y hacer una interpretación

${ }^{18}$ Entre otros, Arturo Alessandri R., Manuel Somarriva U., Antonio Vodanovic H., Tratado de Derecho Civil. Partes preliminar y general, Santiago, Editorial Jurídica de Chile, 1998, vol. 1, p. 489; Corral Talciani (n. 12), p. 77; Díez Schwerter (n. 9), pp. 103-105 y Domínguez Hidalgo (n. 14), p. 654 y ss.

19 "La acción civil para obtener la indemnización de daños y perjuicios derivada de delitos penados en esta ley se regirá por las reglas generales.

La comisión de los delitos de injuria y calumnia a que se refiere el artículo 29, dará derecho a indemnización por el daño emergente, el lucro cesante y el daño moral".

${ }^{20}$ Así se advierte en Corral Talciani, Hernán, "Sobre la responsabilidad civil de los periodistas y de los medios de comunicación social por atentados a la honra, intimidad e imagen”, en Información Pública, vol. 4, N² 2, Santiago, 2006, p. 22; RodríGuez Grez (n. 10), p. 316 y ss., entiende que el artículo se referiría sólo a las "meras imputaciones injuriosas", esto es, de una magnitud menor.

${ }^{21}$ Por el contrario, se ha entendido que el art. 2331 del $C C$ debe ser interpretado en el sentido de restringir la reparación de los daños morales, sin atender a si el atentado contra el honor constituyó o no un delito criminal, véase Orlando TAPIA SuÁREZ, De la responsabilidad civil en general y de la responsabilidad delictual entre los contratantes, $2^{\mathrm{a}}$ ed., Santiago, LexisNexis, 2006, p. 236. 
más "optimista", recordando, sobre todo, que a la época de la dictación del Código el daño moral no era indemnizable y que en ninguno de sus preceptos se hizo referencia esa clase de perjuicio, por lo que no habría motivo para pensar que al redactarse el art. 2331 del $C C$ se estaba obviando a los daños no patrimoniales (un camino similar se siguió en su oportunidad, para defender la procedencia de esta clase de perjuicios en sede contractual, considerando que el art. 1556 del $C C$ también alude sólo al "daño emergente y lucro cesante"). En este orden de ideas, el art. 2331 del $C C$ no contendría una excepción, y su aplicación práctica se reduciría a dos aspectos:

- uno, que el daño que se reclame por lesiones al honor debe ser probado (lo que no es más que repetir la regla general, pero que, en la práctica, usualmente no se sigue en caso del honor) y

- que en caso de acreditarse la veracidad de la afirmación "injuriosa", no se dará curso a la indemnización.

En todo caso, lo cierto es que la doctrina ha interpretado la norma como se señaló al principio ${ }^{22}$, y, en ese orden, ha insistido en su eliminación.

\section{El artículo 2.331 ante el Tribunal Constitucional}

El nuevo escenario de control de constitucionalidad que introdujo la ley $\mathrm{N}^{\mathrm{o}}$ 20.050 el año 2005, que implica principalmente que la competencia para conocer las cuestiones de inconstitucionalidad de normas en vigor corresponde ahora al TC y que puede derivar en que el órgano disponga la derogación de una norma legal, ha repercutido en la suerte del artículo 2331 del Código Civil. En efecto, hasta la fecha, el TC lo ha declarado inaplicable por inconstitucional, en al menos seis ocasiones, de siete requerimientos. La primera fue mediante la STC del 10 de junio del 2008, rol 943, resolución que ha servido de precedente para las siguientes, circunstancia que obliga a detenerse en ella.

En pocas líneas, los antecedentes más relevantes de la sentencia son los siguientes: tras ser excluido del estudio jurídico al que pertenecía, un abogado demandó a sus ex socios, solicitando que se le indemnizase el daño moral que le habría causado la "separación unilateral" del despacho de profesionales, ya que se habría afectado gravemente su honor, su intimidad, y "sus derechos como abogado en las relaciones con sus clientes". Durante la tramitación del litigio en primera instancia, dedujo un recurso de inaplicabilidad por inconstitucionalidad del artículo 2331 del Código Civil, ante el TC.

${ }^{22}$ Además, en Gonzalo Linazasoro Campos, "Artículo 2331 del Código Civil: Las razones de su inaplicabilidad por inconstitucionalidad", en Departamento de Derecho Privado, Universidad de Concepción, Estudios de Derecho Civil V, Santiago, AbeledoPerrot, 2010, p. 763. 
El principal fundamento del recurso era que la norma aludida generaría un efecto contrario al respeto y protección de la vida privada y honra del recurrente, derechos que el art. $19 \mathrm{~N}^{\circ} 4$ de la Constitución reconoce a toda persona. La redacción del art. 2331 del $C C$, establecería una limitación al ejercicio de los derechos fundamentales que la Constitución no contempla, en circunstancias de que ante imputaciones injuriosas, sólo permitiría solicitar una indemnización por daños de naturaleza patrimonial, y no por los eventuales daños extrapatrimoniales que pudiesen derivarse de los hechos. Éstos, al ser excluidos tácitamente por la norma impugnada, no podrían ser "reparados” por la concesión de una indemnización de perjuicios. Al referirse al fondo del asunto, el TC abordó el problema desde distintas perspectivas.

En primer lugar, y respecto al "rango" o relevancia que corresponde atribuir a un llamado "principio" de responsabilidad civil extracontractual, razonó que éste no se restringe al ámbito legislativo, sino que se encontraría incorporado en el ordenamiento constitucional. Para justificar esta afirmación invocó los arts. 6 y 7 de la Carta Fundamental, que consagran el principio de supremacía constitucional y su fuerza obligatoria directa, y el principio de juridicidad, en el sentido de que ambos encomiendan al legislador determinar las responsabilidades y sanciones que se deriven del incumplimiento de las normas constitucionales. Agregó, además, los arts. 52 y 53, que con152 sagran un estatuto especial de responsabilidad constitucional del Presidente de la República y de otras altas autoridades públicas, y que regulan que el funcionario que sea declarado culpable de los delitos o infracciones ahí señaladas, será juzgado por los tribunales competentes para hacer efectiva la responsabilidad civil por los daños y perjuicios causados al Estado o a particulares. Indicó como otros ejemplos del postulado anterior, al art. 36, que establece la responsabilidad individual o solidaria ${ }^{23}$ de los ministros de Estado por los actos que firmaren, respondiendo personalmente del reintegro de los pagos indebidos; al art. 79, que establece el estatuto de responsabilidad de los jueces por el desempeño de su magisterio y al art. 61, que establece la inviolabilidad de los diputados y senadores por las opiniones que manifiesten y los votos que emitan en el desempeño de sus cargos, y exige desafuero previo cuando se pretenda hacer efectiva su responsabilidad penal.

Se cerró la línea argumental a favor de la existencia de un llamado principio constitucional de la responsabilidad civil, con la alusión a la regulación que la Constitución haría de la responsabilidad extracontractual del Estado, particularmente en el art. 38 (en cuyo inciso segundo se establece que cualquier persona que se vea lesionada en sus derechos por la administración del Estado, podrá reclamar ante los tribunales que determine la ley), y en otras normas aisladas relacionadas con el reconocimiento del derecho de los

${ }^{23}$ Según si firmaron el decreto en forma individual, o en conjunto con otros ministros. 
particulares a ser indemnizados por requisiciones practicadas durante estados de excepción; por los perjuicios que se causen por errores o arbitrariedades judiciales y por las privaciones al derecho de dominio que se causen por expropiaciones. En principio, creo que parece discutible que la responsabilidad civil, contractual y extracontractual, tenga rango constitucional o que deba ser elevada a esa categoría (no se ve tan clara la necesidad). Los argumentos de texto recién señalados son en su mayoría rebatibles, mas la extensión de este debate excede los objetivos fijados en esta ocasión.

Acto seguido, el TC se refirió a la procedencia del deber de indemnizar perjuicios en casos de lesiones a derechos fundamentales. Por aplicación de las "bases fundamentales" del ordenamiento constitucional (que consistirían esencialmente en el reconocimiento de la dignidad de la persona humana; en la "servicialidad" del Estado y en el respeto y promoción de los derechos esenciales del hombre), se entiende que los perjuicios ocasionados por la lesión de los derechos constitucionales son fuente de responsabilidad civil. Esta afirmación parece indiscutible, cuidando observar que parece más razonable entender que la fuente de la responsabilidad civil es el daño derivado de la lesión al derecho constitucional y no la sola lesión al derecho fundamental ${ }^{24}$. Las consecuencias de aceptar esta precisión son trascendentes, y se reflejan principalmente en el problema del art. 2331 (y en materia probatoria). Ahora, respecto a la naturaleza del daño indemnizable, el TC recuerda que puede ser patrimonial o extrapatrimonial, y pareciera definir a este último como el que consiste en el sufrimiento o menoscabo originado por la lesión de un derecho, que no tiene directamente una significación económica. Nuevamente asocia la lesión de derechos subjetivos con la responsabilidad civil, asumiendo una relación que no parece tan clara (basta pensar -como lo han hecho algunos ${ }^{25}$ en los daños causados a las víctimas indirectas [parientes de la víctima] de un accidente, cuyos daños morales no responden a la vulneración o atentado a un derecho subjetivo del que sean titulares), y que como se adelantó en líneas precedentes, puede acarrear complicaciones. Cerró esta línea argumental, afirmando que la regla general en el ordenamiento chileno, es que todo daño patrimonial o extrapatrimonial causado por un acto ilícito debe ser indemnizado, la que se derivaría del texto del inciso primero del art. 2329 del $C C$, y que el art. 2331 del $C C$ impugnado restringe, al impedir demandar una indemnización por los daños morales que se deriven de las imputaciones injuriosas contra el honor o el crédito de una persona. Esta norma sería una excepción a la regla general, regla que el mismo TC ubica ahora en el Código Civil, y no en la Constitución ${ }^{26}$.

\footnotetext{
${ }^{24}$ Pantaleón (n. 10), p. 1.972.

${ }^{25}$ Op. it., p. 1.994 .

${ }^{26}$ Fundamentos jurídicos $19^{\circ}$ y $20^{\circ}$. Los razonamientos son muy similares a los expuestos cuando se defiende la "constitucionalización del derecho civil”, véase DomínGUEz ÁGUiLA (n.
} 
Concluye los fundamentos de su decisión, con una referencia al derecho a la honra y a su relación con el daño moral, en circunstancias de que la Carta Fundamental consagra el respeto al primero, en su art. $19 \mathrm{~N}^{\circ} 4$. Respecto al derecho a la honra, el TC entendió que alude a la reputación, prestigio o "buen nombre" de todas las personas, y que emana

"directamente de la dignidad con que nace la persona humana, un derecho personalísimo que forma parte del acervo moral o espiritual de todo hombre y mujer, que no puede ser negado o desconocido por tratarse de un derecho esencial propio de la naturaleza humana" ${ }^{27}$.

En este orden de ideas, agregó que las vulneraciones a dicha prerrogativa pueden causar ocasionalmente perjuicios de naturaleza patrimonial, pero que en la generalidad de las veces causarán

"una mortificación de carácter físico, un dolor espiritual, un menoscabo moral carente de significación económica mensurable objetivamente".

La relación entre el honor y los perjuicios no patrimoniales, se estructura 154 de forma que ante lesiones o vulneraciones al primero, probablemente se ocasionarán los segundos (con un amplio margen de certeza).

Luego, resolviendo la cuestión de constitucionalidad, concluyó que se debía descartar

“toda interpretación de las normas constitucionales que resulte contradictoria con los aludidos principios y valores rectores de la Carta Suprema. Ello lleva a concluir que, frente a las interpretaciones posibles del alcance de la protección constitucional de un derecho fundamental, deba desecharse la que admita que el legislador pudo regular sus efectos hasta extremos que, en la práctica, imposibilitan la plenitud de su vigencia o comprimen su contenido a términos inconciliables con su fisonomía"28.

En ese contexto, como el art. $19 \mathrm{~N}^{\mathrm{o}} 4$ de la Constitución asegura el respeto y protección de la honra, y como el "efecto natural" de la aplicación del artículo impugnado sería privar de la protección de la ley a los atentados

2), pp. 107-137; para una visión más cauta, Hernán Corral TALCIANI, "Algunas reflexiones sobre la constitucionalización del Derecho privado", en Derecho Mayor, N³, Santiago, 2004, pp. 47-63 y en sentido más crítico, Barros Bourie (n. 15), p. 248 y ss.

${ }^{27}$ Fundamento jurídico $25^{\circ}$.

${ }^{28}$ Fundamento jurídico $32^{\circ}$. 
contra el honor (dado que el daño moral sería el efecto principal de una lesión al honor, o el único), se resuelve que la aplicación del art. 2331 del $C C$ resulta contraria a la Constitución.

Más allá de los reparos que pueda merecer la línea argumental trazada por el TC, pues su misma lógica podría conducir a la declaración de inaplicabilidad no sólo del art. 2331 del $C C$ sino que, también, de otras normas sobre responsabilidad civil, que en cierta forma limitan la reparación (léase prescripción extintiva, capacidad, entre otras ${ }^{29}$, y que no se ve tan clara la necesidad de elevar a rango constitucional el llamado principio de la responsabilidad civil(fenómeno que sí tiene explicación en ordenamientos como el alemán y el italiano, donde la reparación de los daños morales se encuentra restringida en términos generales en el $B G B$ y en el Código Civilitaliano) ${ }^{30}$, la sentencia sentó una especie de "precedente" que ha marcado la suerte de los requerimientos posteriores sobre la materia. En efecto, la STC de 16 de abril de 2009, rol 1.185, reproduce los razonamientos expuestos, para llegar a la misma solución. Luego, la STC de 23 de septiembre de 2010, rol $1.463^{31}$, llega al mismo resultado, mas cuidando admitir que el legislador puede regular las condiciones procesales y los presupuestos de la responsabilidad extracontractual y, en consecuencia, que puede, también, regular la procedencia del daño moral. No obstante, insistió en que en virtud de aquella regulación, el legislador, al establecer limitaciones, debe respetar la esencia de los derechos, procurando no establecer diferencias arbitrarias. En este orden, el art. 2331 del $C C$ sería discriminatorio, pues las personas que han visto menoscabada su honra quedarían en una situación desfavorable, respecto a aquéllas que han sufrido daños derivados de vulneraciones de otra naturaleza ${ }^{32}$. Y en ese contexto, se concluye que la norma afecta la esencia

\footnotetext{
${ }^{29}$ Véase en este sentido, Raúl Letelier Wartenberg, "El jardinero de Santo Domingo", en De Cive. Democracia, Estado y Derecho Público, consultado en línea el 15 e junio de 2001: http://decive.blogspot.com/2008/06/el-jardinro-de-santo-domingo_15html.

${ }^{30}$ Los tribunales de esos países se han visto obligados a auxiliarse en la Constitución para poder evadir las restricciones que tiene la reparación del daño moral en el ámbito legislativo. En nuestro ordenamiento no se ve necesario, desde el instante en que nuestro Código no sólo no limita la reparación sino que, incluso, manda a reparar "todo daño" (a diferencia, por ejemplo, del art. 2059 del Codice, que restringe la indemnización del daño moral, a las situaciones en que la ley lo autoriza). Puede parecer una afirmación audaz, pero creo que aún prescindiendo de los números 1 y 2 del art. 19 de la Constitución, el daño moral debiera ser indemnizado (esto insinuaría BARROS BOURIE (n. 15), p. 250, n. 104, a propósito del art. 1556 y la reparación del daño moral en sede contractual.

${ }^{31}$ Entre ésta y la sentencia anterior hubo otro requerimiento de inaplicabilidad por inconstitucionalidad del art. 2331 del $C C$, pero fue declarado inadmisible, en razón de que la norma no tenía incidencia decisiva en la resolución de la gestión judicial pendiente (STC de 9 de marzo de 2010, rol 1.569).

${ }^{32}$ Fundamento jurídico $24^{\circ}$.
} 
del derecho a la honra y, en este orden, que es "desproporcionada", lo que la hace inaplicable por inconstitucional al caso concreto. Merece dudas que la norma sea discriminatoria, desde el momento en que trata de la misma forma a todos quienes han visto vulnerada su honra, y en ese escenario, no habría desigualdad $^{33}$. Tras ese pronunciamiento, se suceden en el mismo sentido la STC de 9 de noviembre de 2010, rol 1.419, las SSTC de 15 de marzo de 2011, roles 1.679 y 1.741, y la STC de 29 de marzo de 2011, rol 1.798.

Es necesario apuntar que luego se ha planteado la declaración de inconstitucionalidad del art. 2331 del $C C$ (total y parcial), pero en este caso con un resultado adverso. El quórum requerido para la inconstitucionalidad es más alto que el necesario para la inaplicabilidad, lo que incide en que se declare sin problemas la segunda, pero no la primera (aunque en este caso, la mayoría de los ministros estuvo por rechazar la inconstitucionalidad, tanto total como parcial) ${ }^{34}$. No obstante, todo apunta a que la situación en esta sede no debiera cambiar, y que el resultado de los recursos de inaplicabilidad por inconstitucionalidad que se interpongan en adelante, sea previsible.

\section{El artículo 2331 en la jurisprudencia}

Si bien aún es posible encontrarse con resoluciones aisladas que aplican el 156 art. 2331 del $C C$ (como la SCA de Valparaíso de 7 de marzo de 2011, rol 2.186-2010 $)^{35}$, durante estos últimos años las cortes han rechazado aplicar

${ }^{33}$ Hay quienes consideran que el trato discriminatorio se produce, porque al restringirse la reparación sólo a los perjuicios patrimoniales se discrimina a quienes "carecen de activos en su patrimonio", ya que no podrían reclamar indemnización alguna, frente a quienes sí los tienen, pues éstos verían satisfecha -al menos parcialmente- su pretensión indemnizatoria, véase Linazasoro Campos (n. 22), pp. 766-767. Otra lectura, consiste en entender que la discriminación pasa por el trato diferenciado que reciben quienes han visto vulnerado su honor a través de medios de prensa, frente a quienes se ha vulnerado su honor por otras vías, pero tampoco se ve tan clara.

${ }_{34}$ Puede parecer curioso, pero se rechazó la inconstitucionalidad total por seis votos contra cuatro, y la parcial por el mismo margen, pero con combinaciones diferentes (en otras palabras, sería exagerado afirmar que "faltaron" votos para la inconstitucionalidad). Los votos a favor de la declaración de inconstitucionalidad se fundaron en las mismas consideraciones que motivaron las sentencias reseñadas en el cuerpo principal de este trabajo, y los votos en contra, entre otras cosas, por considerarse dudoso que haya motivos suficientes para una declaración de inconstitucionalidad general; y por tratarse de un artículo que contiene dos normas (la limitación a la indemnización y el establecimiento de la llamada exceptio veritatis), y en ese contexto no sería procedente una declaración total de inconstitucionalidad, sino que parcial (la cual también fue rechazada en una votación sucesiva). Para los detalles y fundamentos de los votos, véase la resolución de fecha 24 de mayo del 2011, rol 1.723-10, (recaída en un proceso de inconstitucionalidad iniciado de oficio por el TC).

${ }^{35}$ La demanda se rechaza, además, por no haberse acreditado el daño moral (recurso de casación pendiente). Para identificar otros pronunciamientos relevantes que aplican el 
dicha norma. En este sentido, por ejemplo, la SCA de Santiago de 18 de diciembre de 2008, rol 3.462-2005 ${ }^{36}$. En ésta se dispuso que el art. 2331 del $C C$ es una norma excepcional, y que, en ese orden, se debe interpretar en forma restrictiva y aplicar sólo cuando se trate de delitos contra el honor, como injurias y calumnias. Otra solución destacable es la SCS de 20 de julio de 2009, $3^{\text {a }}$ Sala, rol 6.775-2007, que rechazó aplicar el artículo en una causa por indemnización de perjuicios por la inclusión errónea del demandante en Dicom, concluyendo que en el supuesto de autos se trataba de un hecho material (la inclusión en el boletín), y que la limitación se refiere a imputaciones injuriosas. Y es digna de citarse también, la SCS del 14 de diciembre de 2009, $3^{\text {a }}$ Sala, rol 2.073-2008, que desestimó aplicar el artículo 2331 del $C C$ al caso concreto (la inclusión errónea en Dicom del demandante, por parte del banco demandado), argumentando que la limitación de la norma está dada exclusivamente a las actuaciones dolosas, y no a las culpables, como era el caso de autos. Con esa interpretación, curiosamente, el resultado es que si se vulnera el honor con dolo, se aplicaría la norma y, en consecuencia, la víctima no puede demandar daños morales. Y, por el contrario, si la vulneración es culposa, no se aplica la norma y se pueden demandar daños morales, con lo cual, se "premiaría" al autor del ilícito si actúa con dolo, debiendo ser -por simple lógica- lo contrario.

VI. EL HONOR Y LAS PERSONAS JURÍDICAS

El escenario expuesto hasta ahora se puede complicar otro tanto, si se considera que un sector no menor de los operadores del mercado se encuentran configurados como personas jurídicas. Por este motivo, habría que resolver, además, si es razonable afirmar que las personas jurídicas pueden ser titulares del derecho fundamental al honor. Y hecho esto, resolver si es teóricamente admisible que las personas jurídicas puedan sufrir daños extrapatrimoniales, y que, a su vez, les sean indemnizados pecuniariamente, sobre todo cuando se trata de entidades que persiguen una finalidad lucrativa ${ }^{37}$.

art. 2331, es necesario retroceder en el tiempo. Así, por ejemplo, la SCS de 30 de enero de 2002, rol 4.313-2001, y la SCS de 16 de diciembre de 1996, rol 32.387-95, en la que se señaló expresamente que el art. $2331 \mathrm{del} C C$ era una norma de carácter general, y aplicable no sólo a los casos de delitos de injurias o calumnias.

${ }^{36}$ Por la SCS de 1 de junio de 2011, 4a Sala, rol 1.478-09, se rechazó un recurso de casación interpuesto en contra de la sentencia (se consideró que los hechos no eran constitutivos de "imputaciones injuriosas").

${ }^{37}$ Sobre este problema expuse en las Jornadas Nacionales de Derecho Civil del año 2009, y me remito a lo señalado y discutido en esa ocasión, sin perjuicio de que es necesario, al menos, recordar que, aunque merezca serias prevenciones, la tendencia en doctrina tanto nacional 
El problema de las personas jurídicas y el derecho al honor, es uno de los más polémicos en lo que a la aplicación de derechos fundamentales a personas jurídicas se refiere. A continuación, se expondrá el estado actual de la cuestión en doctrina, realizándose, al mismo tiempo, una revisión de los diversos argumentos con los que se justifican las dos principales posturas (dedicándosele especial atención a los que defienden la titularidad del derecho al honor, dado que se partirá de la premisa de que en principio parece poco convincente que las personas jurídicas puedan gozar de dicha prerrogativa); para luego atender a la cobertura que le ha dado la jurisprudencia al problema.

\section{Las personas jurídicas no son titulares del derecho al honor}

Hay un sector (que en la actualidad se podría calificar como minoritario) de la doctrina comparada ${ }^{38}$ que entiende que las personas jurídicas no son susceptibles de titularizar el derecho al honor. Los principales argumentos con que se niega la titularidad de este derecho consisten -a grandes rasgos- en que el derecho al honor está íntimamente ligado a la dignidad humana $^{39}$ (y, por tanto, a la persona humana), carácter que emana de su supuesto significado personalista ${ }^{40}$; en que la consagración constitucional del honor siempre está orientada a garantizar y facilitar el libre desarrollo de la personalidad de hombres y mujeres, considerados individualmente ${ }^{41}$ y en que conceptualmente -en principio- el honor es imposible de atribuir a sujetos distintos a la persona humana. Es en este último aspecto donde se puede situar la discordia entre quienes defienden la negativa del honor a las personas jurídicas y los que sostienen lo contrario. Si bien para ambas posiciones hay otros argumentos, la forma de entender el honor ${ }^{42}$ es el factor

como comparada es hacia la aceptación de que las personas jurídicas puedan sufrir daños morales, véase las actas contenidas en Departamento de Derecho Privado, Universidad de Concepción, Estudios de Derecho Civil V, Santiago, AbeledoPerrot, 2010, pp. 751-761.

${ }^{38}$ En España niegan que las personas jurídicas sean titulares del honor: Albaladejo (n. 2), p. 493; Ana Laura Cabezuelo Arenas, Derecho a la intimidad, Valencia, Tirant lo Blanch, 1998, p. 193; José Luis ConcePCión Rodríguez, Honor, intimidad e imagen, Barcelona, Bosch, 1996, p. 147 y ss.; Eduardo Estrada Alonso, El derecho al honor en la Ley Orgánica 1/1982, de 5 de mayo, Madrid, Civitas, 1989, p. 102 y ss. y Grimalt Servera (n. 7), p. 45, n. 74.

${ }^{39}$ Grimalt Servera (n. 7) p. 45, n. 74.

${ }^{40} \mathrm{Y}$, por lo tanto, atribuible sólo a personas individualmente consideradas, véase M. Luisa, Balaguer Callejón, El derecho fundamental al honor, Madrid, Tecnos, 1992, p. 145.

${ }^{41}$ Cabezuelo Arenas (n. 38), p. 193.

${ }^{42}$ La perspectiva correcta para resolver el problema, pasaría por el análisis del concepto de honor (más que por el concepto de persona jurídica). Alma María Rodríguez Guitián, "El derecho al honor de las personas jurídicas (Comentario a la STC 139/1995, de 26 de septiembre)", en $A D C$, vol. 49, N², Madrid, 1996, p. 808. 
decisivo a la hora de evaluar si es atribuible a las personas jurídicas, considerando que este derecho siempre ha sido difícil de delinear. En este orden, se entiende que hay diversos conceptos de honor, que se pueden agrupar desde un punto de vista fáctico ${ }^{43} \mathrm{o}$ de un punto de vista normativo ${ }^{44}$. Este último, el concepto normativo de honor (que, si bien no es el que adopta la mayoría de la doctrina, sí parece ser el más adecuado), impide que una persona jurídica lo pueda titularizar ${ }^{45}$, ya que para esta concepción el honor forma parte de la dignidad de la persona y, por tanto, es igual para todos los seres humanos, e invariable, dado que no debiera sufrir alteraciones por la mayor o menor "importancia" del individuo, ni por su conducta ${ }^{46}$. Implica, desde luego, la dificultad de delimitar el contenido de esta dignidad humana, pero esto ya forma parte de un problema distinto que escapa de los objetivos propuestos y que no es necesario resolver ahora tampoco, dado que la sola ligazón a la dignidad humana debiera conducir a que se descarte para las personas jurídicas. El que se entienda al honor desde un punto de vista normativo, es el argumento más trascendente de la posición que niega la titularidad del mismo al honor por las personas jurídicas, pues impide que aquél sea atribuido a éstas, por su propia naturaleza.

Debo admitir que -en principio- me inclino por descartar que se reconozca a las personas jurídicas el derecho al honor, entendiendo por este último, el que tiene rango de derecho fundamental. Mas no necesariamente porque considere que los argumentos señalados sean convincentes, sino que porque en materia de derechos fundamentales (y en este caso, además, de la personalidad), prefiero entender que en principio, sólo le corresponden a la persona física. En este sentido, me parece que los argumentos que se plantean para destruir dicha premisa, y por esa vía, defender que las personas jurídicas sí tienen honor, deben ser de una magnitud suficiente como para despejar cualquier duda al respecto. Y sucede que, al parecer, las razones que se esgrimen en doctrina para conceder la prerrogativa en cuestión a las personas jurídicas son, al menos, discutibles (como se verá en los párrafos que siguen).

${ }^{43}$ A éste se hará referencia en párrafos siguientes.

${ }^{44}$ Se agrega, además, una concepción intermedia. Para un desarrollo de las distintas concepciones véase Pablo SALVAdOR CODERCH, "Introducción: difamación y libertad de expresión", en Pablo Salvador Coderch (dir.), El mercado de las ideas, Madrid, Centro de Estudios Constitucionales, 1990, pp. 56-66.

${ }^{45}$ Carlos Granados Pérez, "Jurisprudencia del Tribunal Supremo sobre el derecho al honor, a la intimidad y a la propia imagen”, en Eduardo TorREs-Dulce Lifante (dir.), Derecho al honor, a la intimidad y a la propia imagen II, Madrid, Consejo General del Poder Judicial, 1998, pp. 139-140.

${ }^{46}$ Estrada Alonso (n. 38), p. 36, observa: "sólo la concepción normativa, identificada en 'el derecho a ser respetado', es capaz de adaptarse a todos los principios que inspiran el texto constitucional, alcanzando un concepto único, estable e igual para todos los ciudadanos”. 


\title{
2. Las personas jurídicas \\ son titulares del derecho al honor
}

\begin{abstract}
En la actualidad, la doctrina mayoritaria comparada ${ }^{47}$ se inclina por defender la titularidad al honor por las personas jurídicas. Los argumentos para
\end{abstract}

${ }^{47}$ Para la doctrina española, véase Manuel ArAgón REYEs, "El derecho al honor de las personas jurídicas y sus posibles colisiones con el derecho de información”, en Revista Jurídica de Estudiantes de la Universidad Autónoma de Madrid, $\mathrm{N}^{\circ}$ 1, Madrid, 1999, p. 26; Federico BeLlo LANDROVE, "Infracciones contra el honor: algunas cuestiones relevantes", en Revista General de Legislación y Jurisprudencia, vol. 92, N 5, Madrid, mayo 1986, p. 729; Luis F. BIENDicho GARcía, "La protección del prestigio comercial de la entidad mercantil frente a los actos difamatorios: los límites del derecho de crítica del consumidor", en La Ley, vol. 1, Madrid, 1999, p. 1.606; Marc CARRILlo, "Libertad de expresión, personas jurídicas y derecho al honor", en Derecho Privado y Constitución, N 10, Madrid, 1996, p. 98; DíEz-PicAzo (n. 2), p. 349; Manuel Ignacio Feliú Rey, ¿Tienen honor las personas jurídicas?, Madrid, Tecnos, 1990, p. 14; Herrero-Tejedor, Fernando, Honor, intimidad y propia imagen, Madrid, Colex, 1994, p. 278; Elvira López DíAz, "El derecho al honor en las personas jurídicas: nuevas tendencias en la jurisprudencia”, en La Ley, vol. 7, Madrid, 2001, pp. 1.394-1.395; Alma María Rodríguez Guitián, El derecho al honor de las personas jurídicas, Madrid, Montecorvo, 1996, p. 113; María E. Rovira SueIro, La responsabilidad civil derivada de los daños ocasionados al derecho al honor, a la intimidad personal y familiar y a la propia imagen, Barcelona, Cedecs, 1999, p. 267 y Pablo

160 Salvador Coderch, ¿Qué es difamar? Libelo contra la Ley del Libelo. Madrid, Civitas, 1987, pp. 39-41. Para la doctrina italiana, véase entre otros: C. Massimo Bianca, Diritto Civile, $2^{\text {a }}$ ed. Milán, Giuffrè, 2002, vol. 1, p. 160; Adriano DE CuPIs, I Diritti della Personalità, Milano, Giuffrè, 1959, vol. 1, p. 234; Umberto Ferrante, "Persone giuridiche, enti di fatto e delitto di difamazione", in Giurisprudenza di merito, vol. 1, Milano, 1985, p. 151; Arianna Fusaro, I diritti della personalità dei soggetti collettivi, Padova, Cedam, 2002, p. 90 y ss.; Francesca Romana Fuxa SAdurny, "Diritti della personalità afferenti le persone giuridiche", in Paolo Cendon (dir.), Gli interessi protetti nella responsabilità civile, Turín, Utet, 2005, vol. 2, p. 596; Calogero GANGI, Persone fisiche e persone giuridiche, $2^{\mathrm{a}}$ ed. Milano, Dott. A. Giuffrè, 1948, p. 230 y Andrea ZoppinI, "I diritti della personalità delle persone giuridiche (E dei gruppi organizzati)", in Rivista di Diritto Civile, N 6 , Padova, 2002, p. 881 (aunque exige un tratamiento distinto que para el honor de las personas físicas, pues su incidencia es distinta). En Francia, por la titularidad del honor de las personas jurídicas, entre otros: Léon Michoud, La théorie de la personnalité morale et son application au droit français. Seconde partie, Paris, Librairie générale de Droit \& de Jurisprudence, 1909, p. 82; Raymond Legeais, "Personne morale", dans Encyclopédie Juridique, 2a ed, Paris, Dalloz, 1991, vol. 6, p. 4; Frank Petrт, "Les droits de la personnalité confrontés au particularisme des personnes morales", dans Dalloz Affaires, $\mathrm{N}^{\circ} 117$, Paris, 1998, pp. 828-829; Geneviève Viney, Patrice Jourdain. Les conditions de la responsabilité. $2^{\mathrm{a}}$ ed. Paris, L.G.D.J., 1998, p. 36 (aunque se refieren a la reputación) y Pierre VoIRIN, Droit Civil, $30^{\mathrm{a}}$ ed. par Gilles Goubeaux, Paris, Librairie Générale de Droit et de Jurisprudence, 2005, vol. 1, p. 79. En Suiza, de la misma forma, véase: Pierre TERcier, Le nouveau droit de la personnalité, Zurich, Schulthess Polygraphischer Verlag Zurich, 1984, p. 76. En Inglaterra la jurisprudencia ha llegado a la misma solución: véase Simon DeAkin, Angus Johnston, Basil Markesinis, Markesinis and Deakin's Tort Law, $5^{\mathrm{a}}$ ed., Oxford, Clarendon Press, 2003, p. 658, pese a las prevenciones que se han planteado por la doctrina, véase la referencia recién citada y J.A. WEIR, "Local Authority v. Critical Ratepayer -A Suit in defamation", 
sustentar esta posición son de la más variada índole, y en general de una contundencia relativa, dado que todos se pueden rebatir sin la necesidad de tener que recurrir a construcciones teóricas muy complejas. Entre las razones más relevantes -y recurrentes- se pueden señalar los siguientes:

En primer lugar, se ha defendido que las personas jurídicas deben ser titulares del derecho al honor, porque en un terreno meramente instrumental, lo que se defiende al proteger el derecho al honor de las personas jurídicas, es el honor de los individuos o colectividades que forman parte de las mismas (en otras palabras, se protege el honor de sus miembros), planteándose una especie de defensa corporativa del honor ${ }^{48}$. Este planteamiento es discutible, dado que desde el momento en que se asume que la persona jurídica es un sujeto de derecho distinto e independiente de los miembros que la forman, se le debe dar un tratamiento diferenciado y abstracto, desentendiéndose la persona jurídica de los sujetos que la componen $^{49}$. Distinto sería el caso de un colectivo no personificado, o la hipótesis en que una persona jurídica asume -en forma corporativa- la defensa del honor de sus miembros, dado que en este último caso, si bien se legitima a la entidad, no se trata de "su" honor, sino el de los individuos que la componen. No se resuelve tampoco qué sucede con las fundaciones, personas jurídicas con sustrato patrimonial que no tienen -en teoría- miembros con

in Cambridge Law Journal, vol. 30, N² , Cambrigde, 1972, pp. 238-246. En Chile Barros Bourie (n. 15), p. 607; Corral Talciani (n. 12), pp. 152-153; Ramón Domínguez Benavente, Ramón Domínguez ÁGuila, "Registro de antecedentes comerciales. Diferencia entre pérdida de vigencia y desaparición física de tales antecedentes. Derecho a la honra y vida privada en relación a personas jurídicas. Comentario a sentencia de la Corte Suprema, de 23 de junio de 1994", en Revista de Derecho de la Universidad de Concepción, № 196, Concepción, 1994, p. 165; Domínguez Águila (n. 12), p. 185 y Alberto Lyon Puelma, Personas jurídicas, Santiago, Universidad Católica de Chile, 2003, pp. 61-62.

${ }^{48}$ Bello Landrove (n. 47), p. 729; Rodrigo Bercovitz Rodríguez-Cano, "Comentario a Sentencia de 15 de abril de 1992”, en Cuadernos Civitas de Jurisprudencia Civil, N 29, Cizur Menor (Navarra), 1992, p. 520.

${ }^{49}$ En la SCS de 13 de febrero de 2002, rol 219-02, se confirmó la SCA de Concepción de 28 de diciembre de 2001, rol 1.909-2001, que había rechazado un recurso de protección interpuesto por los representantes de diversas sociedades que habían sido -supuestamenteinjuriadas a través de medios de comunicación. La Corte señaló: "los recurrentes han pedido amparo y protección para su honra personal en circunstancias que en cualquier caso los presuntos afectados por el proceder de los recurridos son las sociedades que representan, si bien ha de admitirse que el desprestigio de una persona jurídica puede afectar también el honor de sus miembros o el de alguno de ellos. En el caso de autos, los recurrentes han emprendido acción de amparo para su honra personal sin que previamente se determine si se encuentra afectado el prestigio, el nombre de las sociedades que representan, asunto que es básico para la legitimación de sus acciones". Es posible observar que se distinguió el honor de las personas jurídicas, del honor de sus representantes (probablemente socios también), condicionando la protección a los segundos por ofensas a las primeras, a que se hubiese declarado vulnerado el honor de éstas en forma previa. 
honra que defender. En suma, esta posición, al final, no ataca el problema propiamente tal, que consiste en resolver si las personas jurídicas como tales pueden ser titulares del derecho al honor de manera independiente a los miembros que la componen.

Otro argumento que se ha formulado en este sentido, es el que se resume en que la protección del derecho de asociación, es motivo suficiente para extender la tutela de los derechos fundamentales a las personas jurídicas, incluyéndose por esta vía el honor ${ }^{50}$, entre otros. Lo anterior, porque el reconocimiento del honor sería también necesario para el correcto funcionamiento de las personas jurídicas, el que es indispensable para que se cumplan los fines de las mismas y, de esa forma -a la vez-, se asegure el respeto al derecho de asociación ${ }^{51}$. Si bien es, quizá, la posición más satisfactoria, de todas las que se esgrimen para justificar la titularidad general de esta clase de derechos a las entidades personificadas, su aceptación no implica necesariamente que se deban reconocer todos los derechos fundamentales a las personas jurídicas, sino que es un argumento más a favor de un reconocimiento "en general" de aquéllos a las personas jurídicas. Esta tesis tampoco está exenta de objeciones: por un lado, funde la libertad de asociarse a la obtención de personalidad jurídica (lo que en Chile formalmente no ocurre, desde el momento en que el art. $19 \mathrm{~N}^{\mathrm{o}} 15$ de la 162 Constitución distingue el derecho a asociarse sin permiso previo, de la concesión de personalidad jurídica) $)^{52} \mathrm{y}$, por otro, no resuelve el problema para las personas jurídicas de derecho público.

Se ha formulado como un argumento para extender la titularidad del derecho al honor a las personas jurídicas, el que se incluya dentro del honor (y, por lo tanto, se entienda protegido bajo su alero) al prestigio (comercial y profesional), atributo del cual sí serían acreedoras las personas jurídicas. No se negará que estas entidades tienen un prestigio o reputación "social", o si se la quiere llamar, fama. Afirmar lo contrario sería caer en un absurdo. En este orden, como tienen prestigio y forma parte del derecho al honor, se debería concluir que aquéllas son titulares de éste. Mas, se debe tener presente que, si bien es cierto que en el ámbito jurisprudencial y doctrinal, actualmente se reconoce una conexión evidente entre las ideas de honor y prestigio, cabe recordar que no parece tan claro que se trate de instituciones

${ }^{50}$ Herrero-Tejedor (n. 47), p. 278.

${ }^{51}$ Planteada en Ángel J. Gómez Montoro, "La titularidad de derechos fundamentales por personas jurídicas: un intento de fundamentación”, en Revista Española de Derecho Constitucional, año 22, No 65, Madrid, 2002, p. 83 y ss.

${ }^{52}$ Aunque en la práctica, lo usual es que así suceda. A esto se debe agregar que una vez que entre en vigor la ley $\mathrm{N}^{0} 20.500$ (doce meses tras su publicación, en lo que a las modificaciones al Código Civilse refiere), la relación entre asociación y personalidad jurídica se haría aún más estrecha, dado que disminuirán los controles. 
análogas y que merezcan la misma protección. Es -bastante- discutible que las personas jurídicas posean dignidad en tal sentido (dignidad humana), por lo que es lícito preguntarse si tal extensión del concepto (constitucional) de honor hacia el prestigio es aplicable también a las personas jurídicas. A primera vista y en el plano teórico, pareciera ser que no ${ }^{53}$. No se abordará con mayor profundidad la dualidad honor-prestigio ni sus implicancias, pero sí se debe observar que no es plenamente convincente.

Íntimamente relacionado con el argumento anterior y tal vez el más relevante de todos, es el que se resume en que el concepto de honor es de carácter fáctico, y que comprende dos aspectos (o sentidos): uno objetivo, o sociológico, que consiste en el reconocimiento que los demás hacen de una persona (el trato que uno recibe de los demás); y otro subjetivo, o íntimo y personal, consistente en la propia estimación por la persona de su propia dignidad (la apreciación o valoración que cada uno hace de sí mismo). Este concepto de honor es el que acoge la doctrina mayoritaria ${ }^{54}$, sin perjuicio de

${ }^{53}$ El Tribunal Supremo español, en STS de fecha 12 de mayo del 2006, ya razonó en este sentido en una oportunidad, cuando a propósito de una demanda por la "intromisión ilegítima" en el derecho al honor de una sociedad mercantil (dedicada al mantenimiento de las piscinas de una comunidad de vecinos) que había sido calificada como "sociedad fantasma" en un manifiesto elaborado por los presidentes de ciertas juntas de vecinos, señaló - descartando que en los hechos se hubiese atentado contra el honor de la sociedad demandante- que el contenido de la comunicación "ni supone un descalificativo del prestigio que la empresa pueda tener en su ámbito de tráfico, ni en definitiva cabe equiparar el prestigio empresarial o profesional con el honor, que es lo que protegen los arts. 18.1 CE y 1 y 7 LO 1/1.982, pues una cosa es que [...] el ataque al prestigio profesional pueda integrar una transgresión del honor cuando revista cierta intensidad, y otra distinta que se pretenda igualarlos, y ello menos todavía cuando se hace referencia a una sociedad mercantil, a cuyo respecto el alcance de la protección del honor se diluye notoriamente". Cabe destacar que el manifiesto insinuaba que la empresa era utilizada por un ex presidente de una junta para desviar fondos, utilizando la sociedad demandante en sus operaciones contables como "tapadera".

${ }^{54}$ Planteado el honor inicialmente así en Italia por DE CuPIS (n. 47), p. 229 (aunque el concepto correspondería a Specker), es una formulación conceptual con amplia acogida en doctrina: en España, entre otros DíEz-Picazo, Gullón (n. 2), p. 344; en Chile, entre otros: Alfredo Etcheberry, Derecho Penal, $3^{a}$ ed., Santiago, Editorial Jurídica de Chile, 1997, pp. 152153; Gustavo Labatut Glena, Derecho Penal, $7^{\mathrm{a}}$ ed., puesta al día por Julio Zenteno Vargas, Santiago, Editorial Jurídica de Chile, 2005, tomo II, p. 181; Humberto Nogueira Alcalá, "Pautas para superar las tensiones entre los derechos a la libertad de opinión e información y los derechos a la honra y la vida privada", en Revista de Derecho, vol. 17, Valdivia 2004, p. 3; Emilio Pfeffer Urquiaga, "Los derechos a la intimidad o privacidad, a la honra y a la propia imagen. Su protección frente a la libertad de opinión e información”, en Ius et Praxis, $\mathrm{N}^{\circ}$ 1, Talca, 2000, pp. 468-469; Mario Verdugo Marinkovic, Emilio Pfeffer Urquiaga, Humberto Nogueira Alcalá, Derecho Constitucional, $2^{\mathrm{a}}$ ed. Santiago, Editorial Jurídica de Chile, vol. 1, 2005, p. 251 y Alejandro Silva Bascuñán, Tratado de Derecho Constitucional, Santiago, Editorial Jurídica de Chile, 2006, vol. 11, p. 193. 
que no está libre de críticas $^{55}$. La principal objeción que se plantea, es que concibe al honor como un concepto mutable, que puede ir variando en el tiempo y en especial según las distintas convicciones sociales y la conducta del sujeto, lo que trae como consecuencia que haya personas con un nivel mayor de honor que otras, y viceversa (lo que implica un trato desigual). Esta concepción de honor en su vertiente objetiva, permite en teoría que pueda ser atribuido a las personas jurídicas y, en este sentido, se ha resuelto el problema por parte de la doctrina ${ }^{56}$. Sin omitir que el argumento es seductor, no se pueden obviar ciertas observaciones:

- Primero y como presupuesto básico, es importante tener claro que esta forma de definir el honor, si bien es la que acogería la doctrina mayoritaria, no es la única. El concepto normativo ha cobrado cierta fuerza e, incluso, puede que sea el que prevalezca, especialmente por la dificultad que enfrenta el concepto fáctico, que permite concebir un honor diferenciado. Esto, en el sentido de que es posible que ciertos individuos tengan más honor que otros, lo que tratándose de derechos fundamentales, y de la personalidad, es una consecuencia difícil de asumir.

- En segundo lugar, sería interesante aclarar -en otra ocasión quizá- si este concepto de honor fáctico, compuesto por dos vertientes (objetiva y subjetiva), resiste una disociación y puede ser considerado sólo en una faz objetiva. Dicho de otra forma: quienes entienden que el honor es predicable de las personas jurídicas porque pueden tenerlo en su sentido objetivo, están aprovechando uno de los sentidos del honor y desechando el otro (el subjetivo), vale decir, están adoptando una postura respecto al honor que es diferente a la tradicional, que lo entiende compuesto de las dos perspectivas, objetiva y subjetiva.

- Y, en tercer lugar, una observación que no ataca la titularidad del honor por las personas jurídicas por la vía de la concepción fáctica de honor, pero sí la supuesta consecuencia directa de la atribución de honor a las entidades personificadas, que sería que puedan, entonces, sufrir daños morales. En efecto, como se señaló al comienzo,

${ }^{55}$ Véase en Tomás Vidal MaRín, El derecho al honor y su protección desde la Constitución española, Madrid, Boletín Oficial del Estado, Centro de Estudios Políticos y Constitucionales, 2001, pp. 50-51.

${ }^{56}$ En este sentido, justifican que las personas jurídicas tienen honor, especialmente en su vertiente objetiva, entre otros: Vincenzo Cardone, Luigi Boreldi, "Onore", in Paolo CEndon, Gli interessi protetti nella responsabilità civile, Turín, Utet, 2005, vol. 2, pp. 335-336; Carrillo (n. 47), p. 98; Rodriguez Guitián (n. 47), p. 104 y ss; Tomás Vidal Marín, "Derecho al honor, personas jurídicas y tribunal constitucional”, en Indret, vol. 1, N³97, 2007, p. 6, consultado en línea el 9 de abril de 2010: http://www.ifret.com/pdf/397_es.pdf. 
una de las formas de entender a los daños morales es como aquéllos que se generan por la lesión de un derecho de la personalidad. Y, en este sentido, se podría concluir que si tienen honor (en su sentido objetivo), podrían sufrir daños morales.

Pero el problema, en este caso, no se resuelve de una forma tan sencilla. Ya se advirtió lo cuestionable que es el predicamento consistente en que la sola lesión de un derecho de la personalidad, genere daños morales. No se discutirá que tal conclusión es por lo general válida cuando se trata del derecho a la integridad física (en ciertas hipótesis el daño es evidente ${ }^{57}$ : la pérdida de una extremidad, por ejemplo), pero sí que es bastante discutible en aquellos derechos de la personalidad calificados como "morales", léase: honor, intimidad e imagen. ¿Basta la lesión, o es necesario algo más, como un impacto en el sujeto o una consecuencia apreciable? Si se reconoce que la conclusión anterior es -eventualmente- válida, y se asume que las personas jurídicas pueden ser titulares dehonor, se debería también admitir que pueden sufrir daños morales.

Pero en el caso del honor, y más aun cuando se trata de personas jurídicas, lo anterior es también discutible. Esto, porque la dicotomía honor objetivo-subjetivo quizá justifica la afirmación de que la sola lesión al honor (derecho extrapatrimonial) produce daños morales, en tanto el aspecto subjetivo del honor es donde precisamente se identifica el perjuicio, vale decir, el daño extrapatrimonial. En otras palabras, la lesión del derecho se verifica en el aspecto objetivo y el daño se produce porque al mismo tiempo se afecta el subjetivo, que es la propia autoestima del sujeto. Un cambio en esta última, desde luego es una alteración, de mayor o menor entidad según la persona, síquica. En ese orden, se podría decir que en el caso del honor, se disipa satisfactoriamente la crítica al concepto de daño moral que se basta con la sola lesión del derecho, pues en este caso hay lesión (al honor en su sentido objetivo: baja la consideración que la sociedad tiene sobre el sujeto) y un impacto síquico -consecuencia de la lesión- en el sujeto, que se manifiesta en la baja de su propia autoestima (honor subjetivo). Hasta aquí las cosas parecen coherentes, mas el esquema se quiebra cuando es traspasado a las personas jurídicas, las cuales no tienen honor subjetivo. ¿Es suficiente entonces la lesión del honor objetivo para que se generen daños morales? Pareciera que no ${ }^{58}$.

${ }^{57} \mathrm{O}$ se confunde con la lesión del derecho.

${ }^{58}$ Luis-Humberto Clavería señaló al respecto: "la proyección de la personalidad humana, necesitada de protección jurídica en cuanto que, de hecho, puede ser dañada por la maledicencia, la injuria, la calumnia, la difamación o el ultraje, es lo que hemos denominado honor en sentido objetivo, cuya medicina característica es la reparación in natura, consistente en la rectificación o la réplica, siendo lo que hemos llamado honor en sentido subjetivo algo cuya lesión constituye daño moral, dolor psíquico, daño y dolor que 
No se trata de negar en absoluto la procedencia de daños morales en esta hipótesis, sino sólo advertir que la afirmación (aceptada por no pocos autores ${ }^{59}$, de que la lesión al honor genera siempre daños morales, en el caso de las personas jurídicas, merece una revisión. En consecuencia, la titularidad de tal derecho a aquéllas no necesariamente debiera implicar que deban sufrir daños morales. Dicho de otra forma, ctienen honor? Parece discutible, en principio creo que no (por las razones ya expuestas y la que se dirá) y aunque -pese a lo anterior- se concluye lo contrario por la doctrina mayoritaria, que les reconoce al menos honor objetivo, se podría objetar que tal conclusión no basta para defender que es posible que las personas jurídicas sufran daños morales, ya que harían falta más argumentos. En este contexto, si se entiende vulnerado el honor de una persona jurídica, y ésta pretende una indemnización por dicha vulneración, las reglas aplicables debieran ser las mismas si reclama una indemnización por daño no patrimonial, que si demanda una por daño patrimonial (esto es, se deberá acreditar el daño) ${ }^{60}$.

Por otro lado, quienes defienden que sólo los seres humanos son sujetos de derecho y que las personas jurídicas no son más que una disciplina normativa $^{61}$, atribuyen eal honor a las entidades, considerando que sus

sólo son consecuencias - pero no el perjuicio principal- en el caso del ataque al honor en su acepción objetiva". Luis-Humberto Clavería Gosalbez, "Negocios jurídicos de disposición sobre los derechos al honor, la intimidad y la propia imagen", en Consejo GenERAL DEL Poder Judicial, Honor, intimidady propia imagen, Madrid, Consejo General del Poder Judicial, 1994, pp. 344-345. En el mismo sentido, Cabezuelo Arenas (n. 38), p. 51. Esta última es aún más clara: "en el caso del honor subjetivo, lo que importa es el daño moral que sufre la persona contra la que se realiza la intromisión, pudiendo ocurrir que su estima de cara al exterior permanezca inalterable".

${ }^{59}$ Véanse notas 6 y 12.

${ }^{60}$ Se insiste en este punto, porque si bien hay acuerdo en que todo daño debe probarse, en la práctica esta prueba se suele omitir (o evadir) cuando se trata de daños morales, por diferentes vías.

${ }^{61}$ Planteamiento que prácticamente niega la condición de sujeto jurídico de la persona jurídica, la cual no sería más que la personificación de un orden que regula la conducta de varios individuos, un "punto común de imputación de todos aquellos actos humanos determinados por el mismo orden. La llamada persona física es la personificación de un complejo de normas que regulan la conducta de uno y el mismo individuo. El sustrato de la personificación es pues, en principio, el mismo en ambos casos" Hans Kelsen, Teoría general del Derecho y del Estado, México, D.F., Textos Universitarios, 1969, p. 120. Esta tesis ha gozado una cálida acogida dentro de la doctrina italiana, véase por todos Francesco Galgano, Delle persone giuridiche, Bolonia, Roma, Nicola Zanichelli, Foro Italiano, 1969, p. 16 e ss. y tiene ilustres partidarios en España: entre otros, Cándido PAZ Ares, "Capítulo 21. La sociedad mercantil: atributos y límites de la personalidad jurídica. Las cuentas en participación”, en Rodrigo Uría, Aurelio Menéndez, Curso de Derecho Mercantil, $2^{\mathrm{a}}$ ed. Navarra, Thomson Civitas, 2006, vol. 1, p. 569. 
titulares en realidad son los seres humanos tras aquéllas ${ }^{62}$. Vale decir, niegan el honor a las personas jurídicas (porque prescinden de ellas como sujetos de derecho) y, al mismo tiempo, se lo reconocen tácitamente, pues permiten que el honor de los miembros se reconduzca semánticamente a la persona jurídica.

Y, por último, se debe tener presente que se podría utilizar también, argumentos de texto legal. El art. $19 \mathrm{~N}^{\mathrm{o}} 12$ inc. $3^{\circ}$ de la Constitución ${ }^{63}$ reconoce a toda persona natural o jurídica, el derecho a solicitar la rectificación de cualquier información que la ofenda o aluda injustamente, por el mismo medio de comunicación social en el que se emitió la información. La norma podría considerarse ${ }^{64}$ como un argumento de texto a favor de que las personas jurídicas puedan ser titulares del honor, dado que lo que se pretendería al concederles el derecho a exigir rectificación, es protegerles dicha prerrogativa. Esta conclusión parece excesiva, considerando que la interpretación correcta de la norma parece ser en el sentido de que el derecho de rectificación

"no busca exclusivamente la protección del honor, sino que trata de garantizar a todas las personas - privada o pública, física o jurídicael acceso a los medios de comunicación que hayan difundido una información inexacta de hechos que les aludan, y cuya divulgación pueda causarles perjuicios" ${ }^{\prime 5}$.

Puede ser que busque la protección del honor, pero también la de otro interés de quien ha sido señalado en un medio de comunicación, relacionado con informaciones falsas. Es legítimo exigir que dicha información

${ }^{62}$ Francesco Galgano, Diritto Civile e Commerciale, $4^{\mathrm{a}}$ ed., Padova, Cedam, 2004, vol. 1, p. 209; Rovira Sueiro (n. 47), p. 267.

63 “Toda persona natural o jurídica ofendida o injustamente aludida por algún medio de comunicación social, tiene derecho a que su declaración o rectificación sea gratuitamente difundida, en las condiciones que la ley determine, por el medio de comunicación social en que esa información hubiera sido emitida". Este derecho de rectificación está desarrollado en los arts. 16 a 21 de la Ley 19.733.

${ }^{64}$ Así se ha defendido en España en razón del texto de la ley 2/1984, cuyo art. $1^{\circ}$ contiene el derecho a rectificación en términos análogos a la ley chilena, véase Javier PLAzA Penadés, El derecho al honor y la libertad de expresión, Valencia, Tirant lo Blanch, 1996, p. 61; Carlos Javier Rodríguez García, Contingencias varias de Jurisprudencia y Honor, Madrid, Dykinson, 1994, 196 pp. 98-99 y Vidal Marín (n. 55), p. 9.

${ }^{65}$ Manuel Jaen Vallejo, Libertad de expresión y delitos contra el honor, Madrid, Colex, 1992, p. 167. En el mismo sentido, Gema RosAdo IGLESIAS, La titularidad de derechos fundamentales por la persona jurídica. Valencia, Tirant lo Blanch, 2003, p. 201, n. 368 ("la acción de rectificación no prejuzga la declaración acerca de la vulneración del derecho al honor, sino que se dirige a la corrección de informaciones”). 
se rectifique, no siendo indispensable que afecte el honor del aludido, piénsese, por ejemplo, en un estado de situación patrimonial o en cualquier información que contenga datos económicos -falsos- sobre una persona, y que la puede afectar en sus negocios, pero no necesariamente en su honor. Es evidente que tiene derecho a exigir la corrección.

\section{Reconocimiento diferenciado del derecho al honor}

Sin perjuicio de que se cuestione la tesis que defiende que las personas jurídicas sean titulares del derecho al honor, el hecho de que la doctrina se incline por la posición contraria, obliga a examinar, al menos, un aspecto que se ha planteado respecto a la tesis positiva. Se ha propuesto por algunos, distinguir entre diversas clases de personas jurídicas, para afirmar o rechazar que sean titulares del derecho al honor. Así, se ha sugerido que las personas jurídicas sin fines de lucro puedan ser titulares del derecho al honor y las con finalidad lucrativa $\mathrm{no}^{66}$. En principio, no creo que la finalidad lucrativa o, en general, que los fines sean suficientes como para marcar una diferencia en esta materia. Si se asume que los entes morales pueden ser titulares del derecho al honor, condicionar tal reconocimiento a la finalidad -general- perseguida puede ser excesivo. La difamación a 168 una persona jurídica que persigue una finalidad lucrativa, es igual de contundente que para una que no la persigue, en ambos casos la obtención de sus "fines sociales" se verá igual de afectada (si es que es ése el principal aspecto que se quiere proteger, al atribuirles la titularidad del derecho al honor) en mayor o menor entidad según el caso, pero no creo que sea válido generalizar en este sentido.

Otro criterio de distinción propone matizar entre personas jurídicas de sustrato personalista (representado por una colectividad de individuos, universitates personarum) y personas jurídicas caracterizadas por la prevalencia del sustrato patrimonial (universitates bonorum) en el sentido de reconocer honor a las primeras y negárselo a las segundas ${ }^{67}$. Se ha señalado al respecto, en primer lugar, que no es sencillo ubicar en uno u otro substrato a las diferentes clases de personas jurídicas (léase: fundaciones, sociedades mercantiles en general, sociedades anónimas, etc.) y, en segundo lugar (y como consecuencia de lo anterior), que no queda del todo claro por qué se hace la distinción.

${ }^{66}$ Herrero-Tejedor (n. 47), p. 283.

${ }^{67}$ Aunque parece superado, se planteó originalmente en España en el ámbito jurisprudencial, en la STS de fecha 5 de octubre de 1989, a propósito del honor de un partido político. Actualmente, esta distinción ha sido descartada por el Tribunal Supremo (véase la STS de fecha 9 de octubre de 1997, en la que se reconoce el honor de la persona jurídica demandante [una caja de ahorros], pero se resuelve que prima la libertad de expresión [se la había tratado de corrupta en un reportaje periodístico]). 
¿Es porque algunas se vinculan más que otras a la personalidad?68. A mi juicio, pareciera que sí. A lo anterior, se deben agregar otros dos aspectos que son trascendentales: esta distinción necesariamente pasa por asumir que se está protegiendo a los miembros de la persona jurídica, por cuanto cuando no los hay, la persona jurídica no merecería protección. Y tampoco se hace cargo de la calidad de sujeto de derecho independiente, que es la persona jurídica, particularidad que precisamente es la que se ha esgrimido para proteger a los miembros de la persona jurídica en casos de abuso de personalidad jurídica, y que sólo puede ser obviada cuando hay motivos suficientes para proceder al "levantamiento del velo". Esta última hipótesis es la única en la cual el Derecho ha permitido obviar la condición -de la persona jurídica- de sujeto independiente y distinto de los miembros que la componen, precisamente para perseguir a aquéllos que aprovechándose del sustrato de la personalidad jurídica burlan el cumplimiento de un contrato, de una norma jurídica o derechos de terceros ${ }^{69}$. Entonces, ¿̇por qué si aun para sancionar ilícitos su aplicación es excepcional, se debe realizar la misma operación para favorecer a quienes ya se han visto beneficiados con la posibilidad de crear un sujeto independiente y paralelo a ellos? Esto, desde luego, como cuestionamiento a planteamientos que pretenden proteger indirectamente a los miembros de la persona jurídica cuyo "honor" se haya visto vulnerado ${ }^{70}$.

${ }^{68}$ Pablo Salvador Coderch, "El concepto de difamación en sentido estricto", en Pablo Salvador Coderch (dir.), El mercado de las ideas, Madrid, Centro de Estudios Constitucionales, 1990 , p. 223. El autor fue sumamente crítico con esta propuesta de distinción, agregando que el que se promoviese una mayor protección a los partidos políticos era también incomprensible, dado que "es dudoso que el mercado político deba privilegiarse y el mercado tradicionalmente económico (o el laboral, etc.) no: De hecho, la publicación de mentiras es oferta engañosa de mercancía deteriorada tanto en un caso como en el otro" (aunque se debe tener presente que la distinción no apuntaba a discriminar el mercado, sino más bien la estructura de la entidad). En sentido similar, BERCOVITZ RodríGuez-CANO (n. 48), p. 521 y María E. Rovira Sueiro, "El honor de la persona jurídica: una cuestión de hermenéutica constitucional", en Anuario da Facultade de Dereito da Universidade da Coruña, $\mathrm{N}^{\circ}$ 2, Coruña, 1998, p. 474.

${ }^{69}$ Respecto a la cuestión del levantamiento del velo, véase por todos, Carmen BoLdó RodA, Levantamiento del velo y persona jurídica en el Derecho Privado español, $4^{\mathrm{a}}$ ed. Navarra, Aranzadi, 2006, 499 p.

${ }^{70}$ Explicado de otra forma: La concesión de personalidad jurídica o el reconocimiento de la personalidad jurídica es -por regla general- un privilegio (léase en el sentido cotidiano del término) que el ordenamiento jurídico, cumplidos ciertos requisitos, concede a las personas físicas privilegio que va acompañado, incluso, de la limitación de responsabilidad en ciertas formas de personificación, lográndose casi una completa abstracción entre los miembros de la persona jurídica y ésta. En este orden, es coherente que se pretenda resguardar esta diferenciación entre entidad y miembros, para lograr el objetivo de que junto a las personas físicas, funcionen en paralelo las jurídicas. Y a la vez, que sólo excepcionalmente, se rompa 


\section{La protección paralela del prestigio o "buena fama"}

El que se niegue el derecho al honor a las personas jurídicas no implica que no se les reconozca otra clase de prerrogativas similares. Se trata de distinguir el derecho al honor del "buen nombre" o "buena fama" (y del prestigio, considerado en un sentido más amplio que el que se identifica con el derecho al honor), indicando que, si bien las personas jurídicas no pueden ostentar aquél, se debe reconocer que sí son acreedoras de los últimos, atributos o caracteres que son también dignos de protección.

Asumir esto, implica que aun negando la posibilidad de que las personas jurídicas sean titulares del honor, queda abierta la puerta a eventuales indemnizaciones derivadas de lesiones al aludido "buen nombre" o "buena fama". Pero la situación es distinta, porque ya no se podrá dar esa especie de relación causa-efecto (discutible, pero comúnmente aceptada) entre la lesión del derecho de la personalidad y la ocurrencia de daños morales, dado que no se estará afectando un derecho de la personalidad propiamente tal, sino que una figura distinta. Es cierto que parece una objeción sólo conceptual, pero es trascendente precisamente porque es conceptual también la construcción teórica sobre los daños morales, que los entiende causados automáticamente por lesiones a derechos de la personalidad. 170 Entonces, si se recurre sólo a los conceptos para identificar un daño como extrapatrimonial (y tenerlo por causado sin más), lo mínimo es que se den

("perforando") el "velo" de la persona jurídica para sancionar a quienes aprovechándose de la normativa que la regula, pretenden abstraerse de determinadas situaciones jurídicas. Esto es, sólo para sancionar, cuando el Derecho entiende que ya no hay otra posibilidad y como medida de última ratio. Entonces, si sólo para sancionar a quienes sacan provecho ilícito de la personificación se permite prescindir de ella e, incluso, en tal caso se asume como una situación excepcional, no se ve por qué se deba prescindir de la personalidad jurídica y "levantar el velo" (ahora en sentido contrario) para favorecer a los miembros, ya beneficiados previamente con la posibilidad de constituir una persona jurídica. Al formarla, sus miembros se aprovechan de la existencia de una entidad paralela a ellos que (en la generalidad de los casos) responderá de forma independiente por las obligaciones que generen las actividades de la persona jurídica, por lo que no es excesivo exigirles que asuman que lo que le suceda a aquélla, no les debiera afectar (y si sucede, que accionen de forma independiente en nombre propio). Y digo que es un privilegio, porque permite realizar por varias personas a la vez ciertas actividades, alcanzando un nivel de organización, funcionamiento y efectividad muy difícil de lograr, si no se cuenta con un centro de imputación paralelo. Desde luego, esta afirmación es refutable, sobre todo considerando que hay ciertas actividades, económicas y no económicas, en las que el ordenamiento jurídico exige constituirse en persona jurídica (un banco, por ejemplo), circunstancias en las que será discutible que sea un "favor" -ya que más bien no hay otra opción y es por obligación- pero por lo general (e históricamente así ha sido) es un beneficio. Con todo esto, la idea no es desconocer que la personalidad jurídica, teóricamente es mucho más que una mera separación de patrimonios, véase Lyon Puelma (n. 47) p. 38 y ss., sino que advertir que en la práctica lo que trasciende con mayor relevancia, es eso. 
tales conceptos, exigencia que no se cumple si se niega el honor a las personas jurídicas, aun cuando se les reconozca algo similar. Es más, parece más lógico pensar que los atentados al nombre o buena fama (cuando se trata de personas jurídicas) generan daños de naturaleza patrimonial y no extrapatrimonial ${ }^{71}$.

Respecto al problema del prestigio, en último lugar, se debe aludir a una interesante postura que señala que las personas jurídicas, si bien no son titulares del derecho al honor, sí son portadoras de una "dignidad social" (paralela a la dignidad humana de las personas físicas), en la cual podrían fundamentar algo similar al honor. Esta especie de dignidad, superaría la humana de cada una de las personas físicas que la componen, y sería equivalente a la "propia identidad y buena reputación social de las personas jurídicas" 72 , siendo trascendente que esta "dignidad social" puede aumentar o disminuir e, incluso, desaparecer (lo que no puede suceder en el caso de la dignidad humana). Es quizá la elaboración teórica más satisfactoria respecto al honor de las personas jurídicas. No se les reconoce como derecho al honor protegido constitucionalmente, pero se admite que las entidades personificadas tienen una fama o prestigio social que puede ser afectado por conductas de terceros. Ahora, esto no implica que puedan sufrir daños morales necesariamente, dado que ya no se trata de la lesión del honor como "derecho de la personalidad", que generaría por esa sola circunstancia daños morales, sino que de una lesión del "buen nombre" o de la "buena fama", cuyos efectos y naturaleza deberán ser analizados conforme a los principios generales de la responsabilidad civil (esto es, si se pretende reclamar daños morales, deberá señalarse en qué consisten y probarse).

\section{Las personas jurídicas y el derecho al honor en la jurisprudencia}

Aunque pueda causar extrañeza, pese a que la doctrina se inclina mayoritariamente por reconocer que las personas jurídicas son titulares de honor, los tribunales han tendido a rechazar dicho planteamiento cuando recurren de protección personas jurídicas. Esto parece más contradictorio

${ }^{71}$ En este sentido, BARros Bourie (n. 15), p. 300. Esto, sobre todo tratándose de sociedades civiles y mercantiles, casos en los cuales las difamaciones por lo general tienen efectos de naturaleza exclusivamente económica, véase Vidal Marín (n. 56), p. 8. Otra cosa, es que sean difíciles de acreditar, y por esa razón se demanden daños no patrimoniales (que, si bien se deben probar también, en la práctica se confunde la intromisión con el daño: probada aquella, prácticamente se presume éste).

${ }^{72}$ Eduardo Estrada Alonso, "El derecho al honor de las personas jurídicas", en Poder Judicial, $\mathrm{N}^{\circ} 13$, número especial, Madrid, 1990, pp. 104-105. 
aún, si se observa que durante estos últimos años, al mismo tiempo han tendido a conceder a personas jurídicas, indemnizaciones de perjuicios por daño moral, por vulneraciones al honor o a la reputación comercial ${ }^{73}$. En el ámbito de Corte de Apelaciones, se pueden citar entre otras: la SCA de Concepción de 31 de agosto de 2005, rol 1.744-200574; la SCA de La Serena de 30 de octubre de 2007, rol 935-2007; la SCA de Concepción de 27 de noviembre de 2009, rol 501-2009 y la SCA de Puerto Montt de 1 de Diciembre de 2009, rol 286-2009. En segunda instancia, la Corte Suprema ha mantenido, por regla general, la misma línea. Se pueden citar en este sentido: la SCS de 8 de noviembre de 1993, rol 21.9345; la SCS de 23 de junio de 1994, rol 23.162 ${ }^{76}$; la SCS de 3 de junio de 1997, rol 3.602-1996; la SCS de 29 de junio de 2000, rol 1.797-2000 77 ; la SCS de 21 de noviembre de 2007, 3 a Sala, rol 4804-2007; la SCS de 7 de enero de 2008 y la SCS de 19 de enero de 2010, $3^{\text {a }}$ Sala, rol 8.140-2009 ${ }^{78}$. Como excepción, se puede

${ }^{73}$ Para la jurisprudencia reciente, véase lo que expuse en su oportunidad, en las actas contenidas en Departamento de Derecho Privado, Universidad de Concepción, Estudios de Derecho Civil V, Santiago, AbeledoPerrot, 2010, pp. 751-761.

${ }^{74}$ Que pese a desconocer que las personas jurídicas tuviesen honor, curiosamente acogió el recurso por considerar que se había vulnerado el derecho de propiedad sobre el prestigio de la entidad (debe ser una de las manifestaciones más extremas del fenómeno de la "cosificación de los derechos").

${ }^{75}$ Confirmó la SCA de Santiago de 14 de octubre de 1993, con la expresa declaración de que por la naturaleza de la recurrente (una sociedad anónima), no podía invocar el art. $19 \mathrm{~N}^{\circ} 4$ de la Constitución.

${ }^{76}$ Véanse comentarios en Domínguez Benavente, Domínguez Águila (n. 47), pp. 162-165.

${ }^{77}$ Revocó la SCA de Santiago de 25 de mayo de 2000, rol 1.119-00, resolviendo el rechazo del recurso de protección, porque el acto en cuestión no habría sido arbitrario ni ilegal, y declarando a mayor abundamiento, que el art. $19 \mathrm{~N}^{\circ} 4$ de la Constitución era aplicable sólo a las personas naturales.

${ }^{78}$ Confirma la SCA de San Miguel de 19 de octubre de 2009, rol 192-2009, que había rechazado un recurso de protección interpuesto por una sociedad de giro inmobiliario y sus representantes, en lo que a la honra de la persona jurídica se refiere. En el fallo de primera instancia se señaló expresamente: "atendido el claro tenor del numeral 4 del artículo 19 de la Constitución Política de la República más arriba transcrito, teniendo especialmente presente la historia fidedigna de su establecimiento precedentemente referida, a juicio de estos sentenciadores, no es posible desvincular el contenido del "respeto... a la honra de la persona... del "respeto a la vida privada y a la honra de... su familia; conceptos que claramente, como lo asentó el constituyente, están referidos y se relacionan sólo y exclusivamente con la persona humana. Lo que a su turno impide discernir, que el amparo constitucional que la aludida norma contempla, y consecuentemente a ello, la protección que a su respecto brinda el artículo 20 de la Carta Fundamental, se extienda, comprenda o alcance, el derecho de los entes ficticios dotados de personalidad jurídica, al buen nombre, fama, crédito o reputación; respecto de quienes por consiguiente necesariamente ha de concluirse, no es factible atribuirles la condición de 'destinatarios de la garantía constitucional de que se trata"” (Fundamento jurídico $18^{\circ}$ ). 
citar la SCS de 4 de junio de 2008, rol 1.736-2008, 2a Sala, que resolvió en sentido contrario, admitiendo que las personas jurídicas son titulares del derecho al honor (se debe considerar que no se trató de un recurso de protección, y que pese a reconocer que pueden titularizar el derecho al honor, descartó que pudiesen ser sujeto pasivo del delito de injurias).

\section{Cuestiones Pendientes}

Además de los temas expuestos en los párrafos anteriores, es necesario abordar con profundidad otras aristas del problema, cuya relevancia no es menor. A continuación, se enunciarán las que parecen más relevantes.

\section{La necesidad de la divulgación}

Parece razonable preguntarse si es necesario que se divulguen los hechos o discursos en los que consiste la lesión al honor, para que se genere responsabilidad y la consiguiente obligación de indemnizar. La Corte Suprema se ha pronunciado en más de una ocasión en el sentido de exigir la divulgación de los hechos, para que se entienda vulnerado el honor del demandante. En la SCS de 26 de septiembre de $2006^{79}$, se rechazó la demanda en contra de un banco que había mantenido por error en sus registros internos a un deudor como moroso, sin publicarlo en el boletín comercial. En primera instancia se había acogido la demanda y la Corte de Apelaciones ${ }^{80}$ había confirmado la sentencia, manteniendo una indemnización de diez millones de pesos por daño moral. Si bien se resolvió la cuestión por no cumplirse los requisitos exigidos por la ley $\mathrm{N}^{0} 19.628^{81}$ (no hubo "tratamiento indebido de datos"), fue relevante que la deuda no se hubiese comunicado a terceros. Y en la SCS de 15 de noviembre de $2010^{82}$, se revocó la sentencia de primera instancia ${ }^{83}$ que había acogido un recurso de protección, interpuesto por un sujeto que había recibido insultos y amenazas por teléfono y correo electrónico. La falta de divulgación de las expresiones fue el argumento principal $^{84}$ de la Corte Suprema para rechazar el recurso, la que entendió

${ }^{79}$ Rol 514-2005, en Fallos del Mes, No 537, Santiago, 2055-2006, p. 2.353.

${ }^{80}$ SCA de Arica de 30 de noviembre de 2004, rol 499-2004.

${ }^{81}$ Sobre protección de la vida privada o protección de datos de carácter personal.

${ }^{82}$ Rol 6.877-2010.

${ }^{83}$ SCA de Concepción de 27 de agosto de 2010, rol 267-2010.

${ }^{84}$ En el fallo se indicó que, de los hechos invocados por el recurrente, "no se desprende una perturbación o amenaza a la vida privada del señor Torres, a su honra o la de su familia, pues dichas comunicaciones han permanecido en el ámbito privado, sin que se haya acreditado su divulgación pública. De este modo, y como lo indica el voto disidente, tales 
que era requisito esencial para que se configurase una vulneración al honor, que ésta fuese divulgada públicamente ${ }^{85}$.

Respecto a esta cuestión, no deja de ser interesante que la ley española, sobre protección a al honor, intimidad y propia imagen (1/1982), en su texto original, al definir la "intromisión ilegítima", exigía la divulgación de los hechos. El año 1995 la norma fue modificada ${ }^{86}$, eliminándose la exigencia de la publicidad (generándose objeciones en el ámbito doctrinal) ${ }^{87}$, con lo que actualmente no es necesario divulgar las expresiones o hechos referidos a la víctima, para que se configure una "intromisión ilegítima". En principio, creo que debiera exigirse divulgación de los hechos o expresiones en que se radica la vulneración al honor, al menos si se pretende reclamar una indemnización por daños morales (éstos se generarían una vez que terceros tienen conocimiento de la vulneración, y no antes).

\section{El honor de los fallecidos}

Otra pregunta pendiente, consiste en determinar qué sucede cuando el sujeto cuyo honor se vulnera, ha fallecido (¿tienen honor los muertos?, el principio en esta materia siempre ha sido que los derechos de la personalidad se extinguen junto con su titular $)^{88}$. Descontando eventuales

174 acciones de los familiares por el daño que la vulneración les cause en su propia honra, en las que reclamen daños sufridos personalmente, parece contradictorio disponer que se indemnicen perjuicios extrapatrimoniales, cuando no hay víctima (pero, por otra parte, tampoco parece adecuado dejar en la indefensión a los familiares del fallecido, quienes querrán velar

comunicaciones se han circunscrito al concepto de honra subjetivo, esto es, el aprecio que cada uno tiene de sí mismo, y por ello, no alcanzan a alterar la reputación o buena fama del quien recurre" (Fundamento jurídico $4^{\circ}$ ).

${ }^{85}$ Además de los fallos citados, se puede agregar aquí la SCA de Concepción de 26 de junio de 2009, rol 856-2008, en la que se revocó una sentencia de primera instancia que condenaba al banco demandado a indemnizar al actor (por su inclusión errónea -durante varios años- en la lista de deudores morosos en un registro de la Superintendencia de Bancos) en la suma de doscientos cincuenta millones de pesos, rechazando la demanda. Si bien el motivo principal fue la ausencia de prueba del daño, se tuvo en consideración que la información nunca estuvo disponible al público. La resolución es interesante además, porque invoca el principio que impone a la víctima el deber de mitigar el daño.

${ }^{86}$ En el contexto de una reforma al Código Penal. Ley 10/1995.

${ }^{87}$ Véase, por ejemplo, Mariano YzQuierdo Tolsada, "Daños a los derechos de la personalidad (honor, intimidad y propia imagen)”, en L. Fernando REglero CAmpos (dir.), Tratado de responsabilidad civil, $4^{\mathrm{a}}$ ed., Navarra, Thomson Aranzadi, 2008, vol. 3, p. 344, quien entiende que debería haber cierto nivel de divulgación para que se configure la "intromisión ilegítima" (y recuerda que, según su definición, "la fama no se ensucia en privado").

${ }^{88}$ Sobre la cuestión en general, véase María Eugenia BoDAS DAGA, La defensa post mortem de los derechos de la personalidad, Barcelona, Bosch, 2007, p. 151 y ss. 
por el "buen nombre" de sus antepasados $)^{89}$. Habría que distinguir el caso en que la vulneración se realizó en vida del sujeto, en que la vulneración fue posterior a su muerte. En la primera hipótesis, si fallece antes de demandar, se podría entender que renunció a hacerlo, y si fallece tras la demanda, hay dos opciones:

- Una, entender que sus herederos serán acreedores de la indemnización si se obtiene sentencia favorable, siguiéndose las reglas procesales correspondientes para el supuesto del fallecimiento de una de las partes durante el juicio.

- Y otra, transgresora, que consiste en entender que no hay daño moral que indemnizar, en circunstancias de que la víctima del daño ha fallecido y, en ese orden, que "el daño moral no se transmite", aplicando un criterio análogo a aquél que se ha defendido a propósito del daño moral en casos de fallecimiento accidental ${ }^{90}$.

${ }^{89}$ En el sentido de considerar como excepcional una indemnización en esta hipótesis: BARRos Bourie (n. 15), p. 605. Hay quienes opinan que se podría recurrir de protección, lo que parece más discutible aún, véase Humberto Nogueira Alcalá, El derecho a la libertad de opinión e información y sus límites: honor y vida privada, Santiago, LexisNexis, 2002, pp. 131-132. Esta última cuestión, se presentó en la SCS de 16 de julio de 2003, rol 1.961-2003, aunque casi en forma tangencial, por la forma en que se resolvió el recuso. La sentencia confirmó el fallo de primera instancia, SCA de Santiago de 16 de julio de 2003, véase Revista de Derecho y Jurisprudencia, tomo C, N² 2, Santiago, julio-diciembre 2003, pp. 113-117, que había rechazado un recurso de protección interpuesto por los descendientes -nieto y bisnietos- de Arturo Prat Chacón, con el objetivo de que se prohibiese la exhibición de una obra teatral que desfiguraba la imagen del héroe nacional (se trató del derecho a la honra de la familia de un fallecido). La Corte no consideró relevante que el titular del derecho había perecido. El fallo se fundó en que "el protagonista que en ella figura resulta tan desfigurado (...) que no es posible identificarlo a él con personas determinadas, ni tan siquiera aquella con quien los recurrentes relacionan, y menos confundir los acontecimientos allí narrados con los actos heróicos que realizara el Capitán Prat", cuestión que, sumada al hecho de que se trataba de un vínculo familiar relativamente lejano, no pasó desapercibida para algunos, véase Correa González, Rodrigo P., "Derechos constitucionales", en Revista de Derecho de la Universidad Adolfo Ibánez, $\mathrm{N}^{\circ}$ 1, Santiago, 2004, pp. 586-587. La Corte dejó pasar problemas -en principio- más relevantes, como el conflicto entre el derecho a la honra y la libertad de expresión (por la forma en que falló, pareciera que entendió que el primero primaba sobre la segunda, ya que da a entender que si el protagonista hubiese sido identificable con el personaje histórico, la solución habría sido otra), y la relación que se presenta entre la libertad de expresión con la libertad de creación artística. Al respecto, véase Pedro ANGUITA Ramírez, El derecho a la información en Chile. Análisis de la Ley $N^{\circ} 19.733$ sobre libertades de opinión e información y ejercicio del periodismo (Ley de Prensa), Santiago, LexisNexis, 2005, pp. 107-125; y Domingo Lovera PARmo, "El mito de la libertad de expresión en la creación artística”, en Revista de Derecho, vol. 23, N 1, Valdivia, 2010, pp. 155-180.

${ }^{90} \mathrm{Al}$ respecto, véase Ramón Domínguez ÁGuila, "La acción por daño moral es intransmisible a los herederos de la víctima directa. Comentario a sentencia de la Corte Suprema, de 27 de junio de 2007", en Revista de Derecho de la Universidad de Concepción, $\mathrm{N}^{\circ}$ 219-220, Concepción, 2006, pp. 257-263. 
Se entendería que las víctimas por repercusión sólo pueden demandar por el daño moral que han sufrido en forma personal, y no, además, por el del fallecido, en consideración -entre otras cosas- a que la indemnización pierde su fundamento (procurar satisfacciones a la víctima, que le permitan sobrellevar el perjuicio sufrido), tras el fallecimiento del actor (en este orden, la acción caduca). Es cierto que se trata de una hipótesis diferente a aquélla en la que se reclama el daño moral generado por el accidente que causa la muerte (y en este caso hay más razones para negar la transmisibilidad), pero se debe admitir que la cuestión es discutible. En la segunda hipótesis, sólo sería procedente indemnizar a los herederos (o parientes) si reclaman el daño moral propio, causado por la lesión de su honor "familiar" (con apoyo en el texto de la Constitución), o en una construcción más elaborada, el causado por la aflicción que les produce ver denostada la "memoria" de sus antepasados ${ }^{91}$. En este escenario, ya no cabría aplicar la fórmula "lesión derecho de la personalidad es igual a daño moral", si es que se acepta, dado que el derecho en cuestión se ha extinguido por la muerte de su titular.

\section{Entidades no personificadas}

$176 \mathrm{Y}$ entre otras cuestiones interesantes, se puede señalar el problema que pueden presentar los grupos o las entidades no personificadas (o colectivos indeterminados), ante vulneraciones o ataques a su honor. Hay, al menos, dos problemas:

- uno de legitimación, quién puede demandar a nombre del colectivo,

- y otro de identificación, pues el demandante deberá acreditar la pertenencia al colectivo (en algunos casos puede ser sencillo, mas en otros sumamente complejo), y que las expresiones injuriosas le han causado un perjuicio indemnizable ${ }^{92}$.

${ }^{91}$ En este sentido véase Le Tourneau (n. 8), p. 505.

${ }^{92}$ En España este problema se presentó a comienzos de la década del 1990, a propósito de las expresiones sobre el pueblo judío por parte de un ex jefe de las Waffen S.S., en una entrevista publicada en un medio de prensa escrita. Aunque se limitó a una cuestión de protección constitucional, y no de responsabilidad civil, el que se haya admitido un recurso de amparo en contra del autor de las declaraciones, interpuesto por una persona independiente (de origen judío), marcó un "punto de apertura" en relación con el reconocimiento del honor a entidades en aquel país (sobre el caso en particular, véase Manuel Ignacio Feliú REY, "El caso de Violeta Friedman y el honor del pueblo judío", en Cuadernos Jurídicos, N 10, Madrid, 1993, pp. 75-82 y sobre el problema en general, entre otros, Carmen LÓPEz PEREgrín, La protección penal del honor de las personas jurídicas y los colectivos, Valencia, Tirant lo Blanch, 2000). En nuestro país hay sentencias en la que se reconoce -soterradamente- la protección de la honra a un colectivo, solicitada por uno o más sujetos individuales. En este sentido la SCS de 17 de junio de 1997, que confirmó la sentencia de primera instancia que había acogido un recurso de 
Si bien no se ve objetable que pueda recurrirse de protección, parece menos razonable que se demande una indemnización por daño moral, el actor debería acreditar que es identificable plenamente con el colectivo denostado, y que las expresiones le causaron un daño indemnizable.

\section{EL ESTADO DE LA CUESTIÓN EN LA JURISPRUDENCIA NACIONAL}

Si se contrasta todo lo anterior con lo que actualmente sucede en los tribunales chilenos, el resultado no sorprende. Si bien en Chile no se habría producido una judicialización llamativa de los conflictos entre personajes televisivos y "famosos", respecto a vulneraciones de su honor o intimidad, o a usos indebidos de su imagen, fenómeno que sí se ha presentado en otros países con idiosincrasia similar a la nuestra ${ }^{93}$, sí se ha ido generando en forma sostenida, jurisprudencia sobre casos de responsabilidad civil por lesión a la honra. Específicamente, por afectarse el prestigio o la reputación ajena, los cuales, por regla general, se centran en publicaciones erróneas o indebidas de la situación financiera de personas naturales o jurídicas en bases de datos públicas de información patrimonial, y salvo excepciones, suelen acogerse las acciones por indemnización de daños morales y, al mismo tiempo, rechazarse las pretensiones de lucro cesante ${ }^{94}$. La base de

protección interpuesto por determinadas personas naturales, a nombre propio, y de "Nuestro Señor Jesucristo, la Iglesia Católica”, en contra del Consejo de Calificación Cinematográfica, por la recalificación que había realizado este organismo, permitiendo la exhibición en nuestro país, de la película "La última tentación de Cristo". Los recurrentes invocaron el "respeto y protección a la honra en relación a la persona de Cristo, tanto como Dios como ser humano", abocándose tácitamente la representación de los cristianos en general. Y entre otras, la SCA de Santiago del 8 de Septiembre de 2008, rol 6.555-2007, por medio de la cual se protegió indirectamente la "honra colectiva" de las personas que profesan la religión evangélica. Podría agregarse en esta nota, la SCS de 14 de septiembre de 1996, que confirmó la condena contra Francisco Javier Cuadra, por haber afirmado públicamente que parlamentarios consumían drogas, con lo que se habría vulnerado el prestigio del Congreso. Pero técnicamente parece estar en el límite, pues los conglomerados afectados estaban relativamente definidos, y no hubo problemas relevantes de legitimación (por lo que se debe sumar que se invocó legislación hoy derogada, y que se trató de un caso con implicancias políticas no menores), circunstancias que hacen relativa su relevancia académica, para estos efectos.

${ }^{93}$ Como España o Argentina, por ejemplo.

${ }^{94}$ Como casos excepcionales se pueden citar la SCA de Santiago del 23 de noviembre de 2006, rol 293-2002, en la cual se acogió la demanda de indemnización de perjuicios, concediéndose al actor la suma de cinco millones y medio de pesos por lucro cesante y un millón y medio de pesos por daño moral. El juicio se motivó por la inclusión del demandante en Dicom, no obstante estar al día en el pago de las cuotas del crédito por el cual se informó moroso (la Corte Suprema rechazó, por manifiesta falta de fundamento, el recurso de casación interpuesto por el demandado [SCS del 11 de abril de 2007, rol 828- 
datos más conocida de esta naturaleza en Chile es Dicom, y actualmente es posible señalarla casi como el "denominador común" de la mayoría de las causas por vulneración de la reputación o buena fama ajena.

En este contexto, primero se debe recordar que la aparente limitación del art. 2331 del Código Civil (que restringiría los atentados al honor sólo a la procedencia de daños patrimoniales), tras ya diversas declaraciones de inaplicabilidad por inconstitucionalidad por parte del TC, pareciera ir lentamente pasando al olvido (como se vio, pese a ser norma vigente, los sentenciadores han empleado soluciones de diversas clases para no aplicarlo). Y segundo, que en estos últimos años es posible observar una disminución de los montos de las indemnizaciones que se conceden por los tribunales, considerando casos similares. Atrás parecen haber quedado indemnizaciones por quince millones de pesos o más (como la SCA de Santiago de 31 de marzo del 2003, confirmada por una de la Corte Suprema de 10 de noviembre de $2004^{95}$, sin que se hubiese acreditado el daño en autos; la SCS de 28 de octubre de $2003^{96}$ y la SCA de Santiago de 16 de diciembre de $2005^{97}$, en la que el monto de la indemnización por daño

2007]). Y la SCS de 30 de noviembre de 2006, $3^{\text {a }}$ Sala, rol 7-2005, en la que se ordenó al banco demandado indemnizar a una sociedad de responsabilidad limitada, por el daño que le habría causado su inclusión errónea en bases de datos de información financiera, como morosa en el pago de un crédito en el que estaba al día. Producto de su inclusión como morosa en Dicom, al menos otros tres bancos de la plaza no renovaron líneas de crédito a la sociedad, y ésta habría perdido, al menos, una oportunidad real de negocio (no habría podido cerrar un contrato de compraventa de veinte camiones). La Corte Suprema revocó la parte de la sentencia de segunda instancia, que ordenaba indemnizar a los socios de la sociedad demandante en forma paralela, y confirmó las indemnizaciones a la sociedad, tanto por daño moral como por lucro cesante, véase la SCA Concepción de 9 de noviembre de 2004, roles 2.909-2001 y 391-2003 (acumulados), que originalmente concedió veinte millones por daño moral a la sociedad demandante, ocho millones por daño moral a cada socio y cuarenta millones a la sociedad por concepto de lucro cesante.

${ }^{95}$ Rol 1.717-2003. La sentencia de la Corte de Apelaciones había rebajado el monto de la indemnización a esa suma, dado que el monto en primera instancia se fijó en treinta millones. El pleito se originó por la inclusión errónea del demandante, en Dicom.

${ }^{96} \mathrm{El}$ monto se fijó en veinte millones de pesos, $2^{\text {a }}$ Sala, rol 1.654-2002. En la resolución, se acogió una pretensión de daños morales al Hogar de Cristo, causados por un delito de la apropiación indebida en su contra. Sin referencias a pruebas en los autos, la Corte señaló que, si bien el perjuicio no se constituía por la merma en las dádivas que usualmente recibía la demandante antes de ocurrir los hechos, ésta sí era un indicio al menos de que se había causado un daño moral. Nótese que se trata de una persona jurídica si fines de lucro.

${ }^{97}$ Rol 6.316-2004. Se concedió la indemnización a una sociedad anónima dedicada a la fabricación, distribución y venta de alimentos para animales, por la campaña de desprestigio llevada a cabo por uno de sus clientes luego de que falleciera inusitadamente un número considerable de sus cabezas de ganado. Se debe tener presente que no se trata de uno de los supuestos habituales de desprestigio (no hay un boletín comercial de por medio), y que la demandante era una persona jurídica 
moral se fijó en cien millones de pesos) ${ }^{98}$, ya que actualmente, por regla general no sobrepasan los diez millones de pesos, y usualmente se fijan en cifras cercanas a los cinco millones de pesos o inferiores, considerando que la hipótesis fáctica en relación con la víctima es similar, y que lo único que varía es la conducta del autor del ilícito, en el sentido de que es más o menos excusable el error, y más o menos displicente su proceder al momento de ser requerido para subsanarlo. Estos aspectos suelen motivar implícitamente las sentencias con montos más elevados, constituyendo manifestaciones evidentes de aplicación de sanciones civiles en el campo de la responsabilidad civil, contractual y extracontractual. Como un caso reciente excepcional, se puede citar la SCA de Santiago de 18 de diciembre de 2008, rol 3.462-05 ${ }^{99}$, en la que se confirmó la sentencia de primera instancia ${ }^{100}$, que había condenado al banco demandado a indemnizar al actor en setenta millones de pesos por daño moral. Es relevante destacar, que el demandante fue incluido erróneamente en Dicom por el demandado, en dos oportunidades (tras reclamar por la primera inclusión y ser sacado de los registros, fue incluido nuevamente unos meses después). Y, por otro lado, que se acogió la indemnización por daño moral íntegramente, cuando, al mismo tiempo, se rechazaron todas las partidas de daño patrimonial solicitadas, en circunstancias de que algunas parecían razonables y verosímiles, y que no hay constancia en la sentencia de consecuencias dañosas extrapatrimoniales de un calibre tal que justifique una indemnización tan elevada por ese concepto ${ }^{101}$.

${ }^{98}$ Y la SCA de Santiago de 3 de enero de 2008, rol 8.216-2003, que rebajó el monto de la indemnización de veinticinco a veinte millones de pesos (por la SCS de 7 de septiembre de 2009, rol 1.870-2008, $1^{\text {a }}$ Sala, se rechazó el recurso de casación interpuesto contra el fallo de la Corte de Apelaciones). El pleito se motivó por el cargo erróneo en la cuenta corriente del demandante, por la suma de cuarenta y dos millones de pesos por concepto de impuesto de timbres y estampillas, en lugar de $\$ 4.200$. Sin perjuicio de que el error fue corregido de inmediato, posteriormente se le cargó una comisión e impuesto por el sobregiro derivado del primer cargo, lo que causó que se sobregirara y le protestaran un cheque. Se debe destacar (y los tribunales lo señalaron como un motivo relevante para bajar el monto de la indemnización) que el demandante no alcanzó a ser incluido en Dicom. Este punto no deja de ser interesante, dado que -como se señaló en páginas anteriores- no se ha discutido en profundidad si es necesaria la publicidad o no de la vulneración al honor, para que se produzca un daño indemnizable.

${ }^{99}$ Ya citada a propósito del problema del art. 2331 del $C C$, apartado V.3.

${ }^{100}$ Sentencia del $14^{\circ}$ Juzgado Civil de Santiago, de 21 de marzo de 2005, rol C-57902002.

${ }^{101}$ Se podrían agregar además aquí, la SCA de Santiago de 2 de septiembre de 2010, rol 6.734-2009, en la cual se fijó el monto de la indemnización en veinte millones de pesos, con la particularidad de que en este caso se acreditó un "cuadro ansioso generalizado y sintomatología de tipo depresiva-ansiosa", mediante testigos y certificados de un médico siquiatra y de un sicólogo, causados por la inclusión errónea del demandante en Dicom; 
Como se señaló, durante estos últimos años es poco usual encontrar sentencias en que se supere o se llegue a los diez millones de pesos (por ejemplo, la SCA de Concepción de 20 de abril del $2009^{102}$, producto de la publicación errónea en Dicom a la víctima se le bloquearon sus tarjetas y su acceso a crédito en plena época navideña), y la regla general es que el techo sea cinco millones, dentro del cual el rango no es menor. Frente a hechos similares, hay fallos por ese monto (por ejemplo, la SCA de Santiago del 12 de noviembre de $2007^{103}$, por el "menoscabo en la fama comercial" del demandante por un protesto indebido de cheques, que derivaron en su publicación en Dicom y -entre otras- la SCA de Concepción del 15 de noviembre de 2007, por la publicación de una deuda por cincuenta y tres millones que el demandante no había contraído jamás, sin prueba del daño en autos) ${ }^{104}$; por tres millones (por ejemplo, la SCA de Concepción

y la SCA de Concepción de 1 de diciembre de 2010, rol 955-2010, en la que se revocó la sentencia de primera instancia que rechazaba la demanda, y la acogió fijando el monto de la indemnización en veinticinco millones de pesos. Respecto al daño, la Corte señaló: "se regulará prudencialmente por esta Corte el monto de la indemnización, tomando en consideración la gravedad del hecho, el natural disgusto, preocupación y angustia que la situación que le afectó ha producido en el ánimo del demandante. Recordemos, que el agravio que ha debido soportar el demandante además de privar a éste de su posibilidad 180 de acceder a créditos, lesionó su integridad personal, pues afectó su honor y su prestigio, condiciones que son inherentes a la persona". En ambos casos, hay recursos de casación pendientes en la Corte Suprema.

${ }^{102}$ Rol 1.441-2007. En sentido similar y por el mismo monto, véase la SCA de Concepción de 8 de julio de 2004, rol 726-2003 y la SCA de Santiago 23 de octubre de 2007 , rol 2.689-2003, respecto a la cual, por la SCS de 7 de enero de 2009, $1^{\text {a }}$ Sala, rol 5.814-07, se rechazó la casación interpuesta por el demandado.

${ }^{103}$ Rol 10.579-2002. La Corte de Santiago rebajó el monto de la indemnización, de treinta millones a cinco millones de pesos. En los hechos, el banco demandado había protestado erróneamente un cheque de la demandante, la que ofreció sólo prueba testimonial para acreditar el daño moral. El Tribunal señaló que el "perjuicio para el afectado de un protesto, indebido en este caso, es objetivamente grave ya que puede no sólo comprometer su patrimonio y dejar de ser sujeto de crédito lo que tiende a cercenar fatalmente su potencial económico, sino que también su credibilidad y su capacidad de interactuar en el ámbito financiero y de los negocios, produciéndole, al menos un menoscabo en su buena fama comercial, tal como se desprende de las declaraciones de los tres testigos hábiles, contestes en los hechos y que dieron razón de sus dichos, quedando en esta forma acreditado el daño moral alegado en la demanda de autos".

${ }^{104}$ Rol 3.736-2001, en primera instancia se había fijado el monto de la indemnización en 37 millones de pesos. Se pueden agregar aquí: la SCS de 23 de junio de 2004, $4^{\text {a }}$ Sala, 4.745-02; la SCA de Concepción de 30 de julio de 2004, rol 3.416-2002, sin prueba del daño en autos (con voto disidente en contra); la SCA de Concepción de 19 de julio de 2005, rol 3.520-2004, por el paso a Dicom tras el protesto erróneo de un cheque; la SCA de Concepción de 8 de junio de 2007, rol 3.629-2004. En el pleito que la motivó el actor alegó que el figurar en Dicom le impedía acceder a créditos, y operar con su cuenta corriente (dado que no le aceptaban cheques). La prueba consistió principalmente en declaraciones 
del 15 de diciembre del $2008^{105}$ y la SCA de Concepción del 15 de enero de 2009, por una deuda inexistente, derivada de cobros de mantención de una tarjeta de crédito cancelada) ${ }^{106} \mathrm{e}$, incluso, por un millón de pesos ${ }^{107}$ (tal es el caso de la SCA de Concepción del 30 de enero de 2009, por publicación en Dicom de una deuda inexistente, estando la cuenta corriente de la demandante cerrada) ${ }^{108}$.

\section{CONCLUSIÓN}

En primer lugar, es posible afirmar que pese a las objeciones teóricas que se puedan plantear en la doctrina nacional suele primar la idea de que la

de testigos (de contenido vago), sobre las dificultades que debió enfrentar el demandante por figurar en Dicom y la SCA de Santiago de 22 de enero de 2008, rol 2.244-2003, en la cual se indican como prueba presentada un certificado médico "de enfermedad", y una boleta de honorarios de un sicólogo.

${ }^{105}$ Rol 3.652-2006, la Corte rebajó la indemnización, fijada en primera instancia en 5 millones de pesos.

${ }^{106}$ Rol 3.327-2006. Pasa casi inadvertido que en el $8^{\circ}$ considerando, el tribunal al justificar la cuantía de la indemnización, confiese haber considerado "el proceder de la demanda", en circunstancias de que lo correcto es que se pondere sólo el daño causado a la víctima, sin considerar la conducta del causante del daño. Se pueden citar aquí también la SCA de Concepción 28 de diciembre de 2009, rol 544-2009, motivada en una inclusión errónea en Dicom por una deuda de treinta y nueve millones de pesos (se presentaron testigos para acreditar el daño moral, que habría consistido principalmente en la imposibilidad para el actor, de encontrar trabajo) y la SCA de Concepción de 12 de octubre de 2010, rol 442-2010, en la que demandó la representante de una sociedad comercial, por sí y en nombre de la entidad (la indemnización se concedió, sin mayores comentarios, a la persona natural).

${ }^{107}$ En este rango se puede incluir la SCA de La Serena de 13 de septiembre de 2006, rol 294-2006, motivada en la inclusión en Dicom por el uso de una tarjeta de crédito bloqueada por robo. La cuantía del daño moral se fijó en dos millones de pesos, y la prueba consistió, principalmente, en la declaración de un testigo que afirmó que el actor tuvo que "ver un psicólogo". Muy similar a la anterior y también por dos millones de pesos, la SCA de Rancagua de 1 de agosto de 2007, rol 409-2007, y en ella la prueba consistió en la declaración de un testigo que afirmó que el demandante perdió credibilidad en el sistema financiero. Por el mismo monto, la SCA de Puerto Montt de 8 de septiembre de 2010, rol 177-2010, en la que se señaló que el figurar por error como deudor en un registro financiero, siempre causa dolor y aflicción. Por un monto un poco más alto, se puede encontrar la SCA de Santiago de 6 de junio de 2009, rol 7.967-2007, en la que se concedió una indemnización de dos millones y medio de pesos a la demandante, que fue pasada erróneamente a Dicom por un año y medio (no se acreditó el daño en autos, pero se señaló que el figurar en el boletín, implica indudablemente que fue desprestigiada social y comercialmente).

${ }^{108}$ Rol 4.515-2006. La demandante había sido incorporada erróneamente en la nómina de deudores morosos de Dicom, por una deuda de \$38.822, mas no acreditó daño alguno en autos, circunstancia que se tuvo en consideración al rebajarse la indemnización en segunda instancia (en ese escenario, se debió haber rechazado la demanda). 
lesión a un derecho de la personalidad (como lo es el honor), implica la ocurrencia de un daño extrapatrimonial. Este postulado se suele extender teóricamente, también, a las situaciones en que se defiende el prestigio comercial o profesional, el cual se suele igualar al honor. En este contexto, se debe destacar, además, que la excepción que establecería el art. 2331 del $C C$ ha pasado a ser sólo formal, desde el momento en que los tribunales, por regla general, no la están aplicando ${ }^{109}$, y que en el evento de que lo hagan, es posible predecir que el TC la declarará inaplicable al caso concreto ${ }^{110}$. De esta manera, las indemnizaciones de perjuicios derivadas de lesiones al derecho al honor, se debieran regir en la práctica, por las reglas generales de la responsabilidad civil (obviándose entonces, la limitación).

Respecto a la atribución o reconocimiento del honor a las personas jurídicas, cabe señalar que en el ámbito teórico, se observa una tendencia mayoritaria (y contundente) en sentido favorable. No obstante, creo que la respuesta merece ser, al menos, matizada. Parece más razonable asumir que su reconocimiento público (y social) no es asimilable al derecho al honor de las personas naturales, las cuales merecen un grado de protección mayor. Ahora, esto no debiera implicar que las entidades personificadas no puedan demandar indemnizaciones por vulneraciones a su prestigio o "buen nombre", pero sí que se deba controlar con un criterio más estricto la concesión de indemnizaciones, las cuales, por lo demás, deberían consistir, en la mayoría de los casos, en daños de naturaleza patrimonial.

Hace falta quizá en esta área, normas particulares que resuelvan el problema (y que atiendan los conflictos que presenta el "descrédito" a un sujeto, en el mercado y en su funcionamiento cotidiano), dado que, si bien las limitaciones probatorias tradicionales que afectan a las reclamaciones por lucro cesante parecen teóricamente razonables, en la práctica suelen conducir a resultados injustos para las víctimas. Compensar esos desequilibrios por la vía de concesiones indiscriminadas de indemnizaciones por daño moral, parece poco aconsejable. El riesgo de esta práctica ya se ha advertido en otras ocasiones: puede implicar sanciones civiles encubiertas, y desplazamientos patrimoniales impropios.

Ahora, si se contrasta todo lo anterior con la realidad judicial, se puede constatar que, si bien, por un lado, se suele negar conceptualmente que las personas jurídicas sean titulares del derecho al honor garantizado en la Constitución, por otro, se observa que se acogen demandas de indemnizaciones de perjuicios por daño moral a entidades personificadas, cuando

${ }^{109}$ Como se expuso en su oportunidad, los tribunales en varias ocasiones han construido interpretaciones que conducen a obviar la aplicación del art. 2331 del $C C$, en el caso concreto.

${ }^{110}$ Siempre y cuando se recurra al TC, sea de oficio o a petición de parte. 
reclaman vulneraciones en su honra. Y respecto al tema central del presente estudio, se puede afirmar que por regla general los tribunales suelen seguir los postulados doctrinarios respecto a la dualidad lesión derecho de la personalidad-responsabilidad civil. En las resoluciones analizadas, los juzgadores usualmente descansan en la acreditación del hecho ilícito para -dando por sentado que se ha causado un perjuicio indemnizableconceder indemnizaciones por daños morales, por montos que se han ido armonizando paulatinamente a la baja. Respecto a este último fenómeno, se debe apuntar que en los casos excepcionales (que sobrepasan los diez o quince millones de pesos), se observa una prueba más contundente que en los demás (y que, aunque parezca una curiosidad, las cortes de regiones son más renuentes a establecer montos altos, que la de Santiago). En este contexto, suelen también desechar reclamaciones por lucro cesante, cuando en la mayoría de los casos es el único perjuicio que realmente ha ocurrido.

Todo esto implica que en los hechos, en la vida judicial diaria, pareciera que los tribunales terminan, indirectamente, prescindiendo del perjuicio como elemento esencial de la obligación de indemnizar. El que ocasionalmente señalen que se deriva necesariamente de los hechos de la causa, en casos de esta naturaleza (diferentes a los relacionados con lesiones o fallecimientos), parece excesivo. Como se señaló en párrafos precedentes, parece necesario insistir en que lo deseable sería liberalizar la prueba del lucro cesante, sea por la vía de crear una nueva categoría de daños identificables con los supuestos fácticos en estudio, con sus propias reglas de acreditación, o simplemente sincerar las decisiones judiciales estableciendo sanciones privadas, lo que permitiría al menos contrastar el monto de la indemnización con la conducta del autor del hecho ilícito. Me inclino, a priori, por la primera salida, pero admito que la segunda es también atractiva en esta área de la responsabilidad civil.

\section{BibliografíA}

Albaladejo, Manuel, Derecho Civil, 15ª ed., Madrid, Edisofer, 2002, vol. 1.

Alessandri R., Arturo, Manuel Somarriva U., Antonio Vodanovic H., Tratado de Derecho Civil. Partes preliminar y general, Santiago, Editorial Jurídica de Chile, 1998, vol. 1.

Anguita Ramírez, Pedro, El derecho a la información en Chile. Análisis de la Ley $N^{\circ}$ 19.733 sobre libertades de opinión e información y ejercicio del periodismo (Ley de Prensa), Santiago, LexisNexis, 2005.

ARAGÓn Reyes, Manuel, "El derecho al honor de las personas jurídicas y sus posibles colisiones con el derecho de información", en Revista Jurídica de Estudiantes de la Universidad Autónoma de Madrid, N 1, Madrid, 1999. 
Balaguer Callejón, M. Luisa, El derecho fundamental al honor, Madrid, Tecnos, 1992.

Barros Bourie, Enrique, Tratado de responsabilidad civil, Santiago, Editorial Jurídica de Chile, 2006.

Bello Landrove, Federico, "Infracciones contra el honor: algunas cuestiones relevantes", en Revista General de Legislación y Jurisprudencia, vol. 92, N 5, Madrid, mayo, 1986.

Bercovitz Rodríguez-Cano, Rodrigo, "Comentario a sentencia de 15 de abril de 1992”, en Cuadernos Civitas de Jurisprudencia Civil, N²9, Madrid, 1992.

Bianca, C. Massimo, Diritto Civile, $2^{\text {a }}$ ed. Milano, Giuffrè, 2002, vol. 1.

Biendicho García, Luis F., "La protección del prestigio comercial de la entidad mercantil frente a los actos difamatorios: los límites del derecho de crítica del consumidor", en La Ley, vol. 1, Madrid, 1999.

Bodas Daga, María Eugenia, La defensa post mortem de los derechos de la personalidad, Barcelona, Bosch, 2007.

Boldó Roda, Carmen, Levantamiento del velo y persona jurídica en el Derecho Privado español, $4^{\mathrm{a}}$ ed. Navarra, Aranzadi, 2006.

Bonilla SÁnchez, Juan José, Personas y derechos de la personalidad, Zaragoza, Reus, 2010.

Cabezuelo Arenas, Ana Laura, Derecho a la intimidad, Valencia, Tirant lo Blanch, 1998.

CARrillo, Marc, "Libertad de expresión, personas jurídicas y derecho al honor", en Derecho Privado y Constitución, N 10, Madrid, 1996.

Cardone, Vincenzo, Luigi Borelli, “Onore”, in Paolo Cendon, Gli interessi protetti nella responsabilità civile, Turín, Utet, 2005, vol. 2.

Castán Tobeñas, José, Derecho civil español, común y foral. Tomo tercero. Derecho de obligaciones. La obligación y el contrato en general, $16^{\mathrm{a}}$ ed. revisada y puesta al día por Gabriel García Cantero, Madrid, Reus, 1992.

Clavería Gosalbez, Luis-Humberto, "Negocios jurídicos de disposición sobre los derechos al honor, la intimidad y la propia imagen”, en Consejo General DEL Poder Judicial, Honor, intimidad y propia imagen, Madrid, Consejo General del Poder Judicial, 1994.

Concepción Rodríguez, José Luis, Honor, intimidad e imagen, Barcelona, Bosch, 1996.

Corral Talciani, Hernán, "Algunas reflexiones sobre la constitucionalización del Derecho privado", en Derecho Mayor, N³, Santiago, 2004. Consultado en línea el 12 de junio de 2011: http://corraltalciani.files.wordpress.com/2010/05/ constitu cionali zaciond-privado.pdf)

Corral Talciani, Hernán, Lecciones de responsabilidad civil extracontractual, Santiago, Editorial Jurídica de Chile, 2004.

Corral Talciani, Hernán, "Sobre la responsabilidad civil de los periodistas y de los medios de comunicación social por atentados a la honra, intimidad e 
imagen”, en Información Pública, vol. 4, N² 2, Santiago, 2006. Consultado en línea el 9 de junio de 2011: http://corraltalciani.files.wordpress.com/2010/04/ resp-civil-de-periodistas.pdf).

Correa González, Rodrigo P., "Derechos constitucionales", en Revista de Derecho de la Universidad Adolfo Ibáñez, N 1, Santiago, 2004.

Deakin, Simon, Angus Johnston, Basil Markesinis, Markesinis and Deakin's Tort Law, $5^{\text {a }}$ ed. Oxford, Clarendon Press, 2003.

De Angel Yágüez, Ricardo, Tratado de responsabilidad civil, Madrid, Universidad de Deusto, Civitas, 1993.

De Cupis, Adriano, I Diritti della Personalità, Milano, Giuffrè, 1959, vol. 1.

Departamento de Derecho Privado, Universidad de Concepción, Estudios de Derecho Civil V, Santiago, AbeledoPerrot, 2010.

Díez-Picazo, Luis, El escándalo del daño moral, Navarra, Thomson Civitas, 2008.

Díez-Picazo, Luis, Antonio Gullón, Sistema de derecho Civil. Introducción. Derecho de la persona. Autonomía privada. Persona jurídica, 11 a ed., Madrid, Tecnos, 2005.

Díez Schwerter, José Luis, El daño extracontractual ante la jurisprudencia. Comentarios, Concepción, Universidad de Concepción, Facultad de Ciencias Jurídicas y Sociales. Fondo de Publicaciones, 1995.

Domínguez ÁGuila, Ramón, "Aspectos de la constitucionalización del Derecho Civil chileno", en Revista de Derecho y Jurisprudencia, vol. 93, N 3, Santiago, 1996.

Domínguez Águila, Ramón, "Daño moral contractual. Daño moral de personas jurídicas. Comentario a sentencia de la Corte de Apelaciones de Santiago, de 9 de diciembre de 2003", en Revista de Derecho de la Universidad de Concepción, $\mathrm{N}^{\circ}$ 214, Concepción, 2003.

Domínguez Águila, Ramón, "La acción por daño moral es intransmisible a los herederos de la víctima directa. Comentario a sentencia de la Corte Suprema, de 27 de junio de 2007", en Revista de Derecho de la Universidad de Concepción, No 219-220, Concepción, 2006.

Domínguez Benavente, Ramón, Ramón Domínguez Águila, "Indemnización de perjuicios, daño moral, persona jurídica, relación de causalidad. Leyes reguladoras de la prueba. Documentos emanados de terceros. Comentario a Sentencia de la Corte de Apelaciones de Concepción de 2 de noviembre de 1989", en Revista de Derecho de la Universidad de Concepción, N 190, Concepción, 1991.

Domínguez Benavente, Ramón, Ramón Domínguez Águila, "Registro de antecedentes comerciales. Diferencia entre pérdida de vigencia y desaparición física de tales antecedentes. Derecho a la honra y vida privada en relación a personas jurídicas. Comentario a sentencia de la Corte Suprema, de 23 de junio de 1994" en Revista de Derecho de la Universidad de Concepción, N $^{\circ} 196$, Concepción, 1994.

Domínguez Hidalgo, Carmen Aída, "Los derechos de la personalidad y el principio de reparación integral del daño”, en Carlos Pizarro Wilson, Estudios de Derecho Civil IV, Santiago, LegalPublishing, 2009. 
Estrada Alonso, Eduardo, "El derecho al honor de las personas jurídicas”, en Poder Judicial, $\mathrm{N}^{\circ}$ 13, número especial, Madrid, 1990.

Estrada Alonso, Eduardo, El derecho al honor en la Ley Orgánica 1/1982, de 5 de mayo, Madrid, Civitas, 1989.

Etcheberry, Alfredo, Derecho Penal, $3^{\text {a }}$ ed., Santiago, Editorial Jurídica de Chile, 1997.

Feliú Rey, Manuel Ignacio, "El caso de Violeta Friedman y el honor del pueblo judío”, en Cuadernos Jurídicos, º 10, Madrid, 1993.

Feliu Rey, Manuel Ignacio, ¿Tienen honor las personas jurídicas?, Madrid, Tecnos, 1990.

Ferrante, Umberto, "Persone giuridiche, enti di fatto e delitto di difamazione", in Giurisprudenza di merito, vol. 1, Milano, 1985.

Fusaro, Arianna, I diritti della personalità dei soggetti collettivi, Padova, Cedam, 2002.

FuXA SADURnY, Francesca Romana, "Diritti della personalità afferenti le persone giuridiche”, in Paolo CENDON (dir.), Gli interessi protetti nella responsabilità civile, Turín, Utet, 2005, vol. 2.

Galand Carval, Suzanne, Non Pecuniary Loss Under French Law, in W.V. Horton Rogers (dir.), Damages for Non Pecuniary Loss in a Comparative Perspective, Viena, SpringerWien-NewYork, 2001.

186 Galgano, Francesco, Delle persone giuridiche, Bolonia-Roma, Nicola Zanichelli-Foro Italiano, 1969.

Galgano, Francesco, Diritto Civile e Commerciale, $4^{\mathrm{a}}$ ed., Padova, Cedam, vol. 1, 2004.

Gangi, Calogero. Persone fisiche e persone giuridiche, $2^{\mathrm{a}}$ ed. Milano, Dott. A. Giuffrè, 1948.

Gomez Montoro, Ángel J., "La titularidad de derechos fundamentales por personas jurídicas: un intento de fundamentación”, en Revista española de Derecho Constitucional, año 22, N $^{0}$ 65, Madrid, 2002.

Granados Pérez, Carlos, "Jurisprudencia del Tribunal Supremo sobre el derecho al honor, a la intimidad y a la propia imagen”, en Eduardo TORREs-Dulce Lifante (dir.), Derecho al honor, a la intimidad y a la propia imagen II, Madrid, Consejo General del Poder Judicial, 1998.

Grimalt Servera, Pedro, La protección civil de los derechos al honor, a la intimidad y a la propia imagen, Madrid, Iustel, 2007.

Herrero-Tejedor, Fernando, Honor, intimidad y propia imagen, Madrid, Colex, 1994.

Jaen Vallejo, Manuel, Libertad de expresión y delitos contra el honor, Madrid, Colex, 1992.

Kelsen, Hans, Teoría general del Derecho y del Estado, México, D.F., Textos Universitarios, 1969. 
Labatut Glena, Gustavo, Derecho Penal, $7^{\mathrm{a}}$ ed. puesta al día por Julio Zenteno Vargas, Santiago, Editorial Jurídica de Chile, 2005, tomo II.

Legeais, Raymond. "Personne morale", dans Encyclopédie Juridique. 2a ed., Paris, Dalloz, 1991, vol. 6.

Letelier Wartenberg, Raúl, El jardinero de Santo Domingo, en De Cive. Democracia, Estado y Derecho Público. Consultado en línea el 15 de junio de 2011: http:// decive.blogspot.com/2008/06/el-jardinero-de-santo-domingo_15.html.

Le Tourneau, Philippe, Droit de la responsabilité et des contrats, $7^{\mathrm{a}}$ ed., Paris, Dalloz, 2008.

Linazasoro Campos, Gonzalo, "Artículo 2331 del Código Civil: Las razones de su inaplicabilidad por inconstitucionalidad", en Departamento de Derecho Privado, Universidad de Concepción, Estudios de Derecho Civil V, Santiago, AbeledoPerrot, 2010.

LóPEz DíAz, Elvira, "El derecho al honor en las personas jurídicas: nuevas tendencias en la jurisprudencia”, en La Ley, vol. 7, Madrid, 2001.

López Peregrín, Carmen, La protección penal del honor de las personas jurídicas y los colectivos, Valencia, Tirant lo Blanch, 2000.

Lovera Parmo, Domingo, "El mito de la libertad de expresión en la creación artística", en Revista de Derecho, vol. 23, N 1, Valdivia, 2010.

Lyon Puelma, Alberto, Personas jurídicas, Santiago, Universidad Católica de Chile, 2003.

Michoud, Léon, La théorie de la personnalité morale et son application au droit français. Seconde partie, Paris, Librairie générale de Droit \& de Jurisprudence, 1909.

NogueIra Alcalá, Humberto, El derecho a la libertad de opinión e información y sus límites: honor y vida privada, Santiago, Lexis Nexis, 2002.

Nogueira Alcalá, Humberto, "Pautas para superar las tensiones entre los derechos a la libertad de opinión e información y los derechos a la honra y la vida privada”, en Revista de Derecho, vol. 17, Valdivia, 2004. Consultado en línea el 30 de mayo de 2010: http://www.scielo.cl/scielo.php? pid=S0718-0950200400 0200006\&script $=$ sci_arttext)

Pantaleón, Fernando, Comentarios al artículo 1.902, en Cándido Paz-Ares RoDríguez, Luis Díez-Picazo Ponce de Leon, Rodrigo Bercovitz, Comentario del Código Civil, Madrid, Ministerio de Justicia, 1993.

Paz Ares, Cándido, “Capítulo 21. La sociedad mercantil: atributos y límites de la personalidad jurídica. Las cuentas en participación”, en Rodrigo URíA, Aurelio Menéndez, Curso de Derecho Mercantil, $2^{\mathrm{a}}$ ed. Navarra, Thomson Civitas, 2006, vol. 1.

Peña GonzÁlez, Carlos, "Informe sobre el proyecto de ley de protección del honor y la intimidad de las personas", en Cuadernos de Análisis Jurídicos, Colección Derecho Privado, $N^{\circ}$ 1, Santiago, 2004.

Petit, Frank, "Les droits de la personnalité confrontés au particularisme des personnes morales", dans Dalloz Affaires, N 117, Paris, 1998. 
Pfeffer Urquiaga, Emilio, "Los derechos a la intimidad o privacidad, a la honra y a la propia imagen. Su protección frente a la libertad de opinión e información", en Ius et Praxis, $\mathrm{N}^{\circ}$ 1, Talca, 2000.

Plaza Penadés, Javier, El derecho al honor y la libertad de expresión, Valencia, Tirant lo Blanch, 1996.

Rodríguez García, Carlos Javier, Contingencias varias de jurisprudencia y honor, Madrid, Dykinson, 1994.

Rodríguez Guitián, Alma María, "El derecho al honor de las personas jurídicas (Comentario a la STC 139/1995, de 26 de septiembre)", en $A D C$, vol. 49, $\mathrm{N}^{\circ}$ 2, Madrid, 1996.

Rodríguez Guitián, Alma María, El derecho al honor de las personas jurídicas, Madrid, Montecorvo, 1996.

Rodríguez Grez, Pablo, Responsabilidad extracontractual, Santiago, Editorial Jurídica de Chile, 1999.

Rosado I glesias, Gema. La titularidad de derechos fundamentales por la persona jurídica. Valencia, Tirant lo Blanch, 2003.

Rovira Sueiro, María E., "El honor de la persona jurídica: una cuestión de hermenéutica constitucional", en Anuario da Facultade de Dereito da Universidade da Coruña, N², Coruña, 1998.

Rovira Sueiro, María E., La responsabilidad civil derivada de los daños ocasionados al derecho al honor, a la intimidad personal y familiar y a la propia imagen, Barcelona, Cedecs, 1999.

Salvador Coderch, Pablo, "El concepto de difamación en sentido estricto", en Pablo Salvador Coderch (dir.), El mercado de las ideas, Madrid, Centro de Estudios Constitucionales, 1990.

Salvador Coderch, Pablo, "Introducción: difamación y libertad de expresión", en Pablo Salvador Coderch (dir.), El mercado de las ideas, Madrid, Centro de Estudios Constitucionales, 1990.

Salvador Coderch, Pablo, ¿Qué es difamar? Libelo contra la Ley del Libelo. Madrid, Civitas, 1987.

Silva Bascuñán, Alejandro, Tratado de Derecho Constitucional, Santiago, Editorial Jurídica de Chile, 2006, vol. 11.

TAPIA SuÁREz, Orlando, De la responsabilidad civil en general y de la responsabilidad delictual entre los contratantes, $2^{\mathrm{a}}$ ed., Santiago, LexisNexis, 2006.

Tercier, Pierre, Le nouveau droit de la personnalité, Zurich, Schulthess Polygraphischer Verlag Zurich, 1984.

Verdugo Marinkovic, Mario, Emilio Pfeffer Urquiaga, Humberto Nogueira AlcALÁ, Derecho Constitucional, $2^{\text {a }}$ ed. Santiago, Editorial Jurídica de Chile, 2005, vol. 1.

VIDAL MARÍn, Tomás, "Derecho al honor, personas jurídicas y tribunal constitucional”, en Indret, vol. 1, N³97, 2007. Consultado en línea el 9 de abril de 2010: http://www.indret.com/pdf/397_es.pdf. 
VIDAl MaRín, Tomás, El derecho al honor y su protección desde la Constitución española, Madrid, Boletín Oficial del Estado-Centro de Estudios Políticos y Constitucionales, 2001.

Viney, Geneviève, Patrice Jourdain, Les conditions de la responsabilité. $2^{\mathrm{a}}$ ed. Paris, L.G.D.I., 1998.

VoIrin, Pierre, Droit Civil, $30^{\text {a }}$ ed. par Gilles Goubeaux, Paris, Librairie Générale de Droit et de Jurisprudence, 2005, vol. 1.

Von Bar, Christian, The Common European Law of Torts, Oxford, Oxford Claredon Press, 2000.

WeIR, J.A., "Local Authority v. Critical Ratepayer -A Suit in defamation", in Cambridge Law Journal, vol. 30, $\mathrm{N}^{\circ}$ 2, Cambrigde, 1972.

YzQuierdo Tolsada, Mariano, "Daños a los derechos de la personalidad (honor, intimidad y propia imagen)", en L. Fernando Reglero Campos (dir.), Tratado de responsabilidad civil, $4^{\mathrm{a}}$ ed., Navarra, Thomson Aranzadi, 2008, vol. 3.

Zoppinı, Andrea, "I diritti della personalità delle persone giuridiche (E dei gruppi organizzati)", in Rivista di Diritto Civile, N 6, Padova, 2002. 